\title{
"Eu vou pra \\ Maracangalha, eu vou..." \\ JK e a Distopia Brasiliæ na música popular e nas charges da revista Careta (1956-1960)*
}

\section{“Eu vou pra Maracangalha, eu vou..." $J K$ and Distopia Brasiliæ in popular music and cartoons of Careta magazine (1956-1960)}

\author{
WAGNER CABRAL DA COSTA \\ Professor do Departamento de História \\ Universidade Federal do Maranhão \\ wagner-cabral@uol.com.br
}

\begin{abstract}
RESUMO Análise da relação entre música popular e charges satíricas sobre a fundação de Brasília, publicadas na revista humorística Careta. A iniciativa de construção da nova capital pelo governo de Juscelino Kubitschek foi objeto de acesa polêmica, dividindo a opinião pública, além de ser contestada pela União Democrática Nacional - UDN (principal partido de oposição). Inicialmente, investigam-se os usos sociais e apropriações da música popular para fazer a crítica ao projeto de JK. Depois, examinam-se as afinidades entre a revista de humor e a grande imprensa, compartilhando a oposição ao governo federal, bem como a defesa da cultura política liberal. Em seguida, analisa-se a polêmica musical de Brasília, envolvendo diferentes sujeitos, gêneros e práticas sociais. Por fim, através da avaliação da série iconográfica, estudam-se as disputas pelo imaginário social da nova cidade, reinventada como utopia negativa, a distopia Brasiliæ.
\end{abstract}

Artigo recebido em: 01/12/2011. Aprovado em: 30/03/2012. 
Palavras-chave charge política, revista Careta, música popular, cultura política liberal

ABSTRACT Analysis of the relationship between popular music and satirical cartoons about the foundation of Brasília, published in Careta (humor magazine of Brazil). The initiative to construct the new capital by the government of Juscelino Kubitschek was the object of fierce controversy, dividing public opinion, besides being challenged by the National Democratic Union - UDN (main opposition's party). Initially, we investigate social uses and appropriations of popular music to criticize JK's project. Then, we examine the affinities between humor magazine and mainstream media, sharing the opposition to the federal government, as well as the defense of liberal political culture. Hereafter, we analyze the musical controversy about Brasília, involving different subjects, genres and social practices. At last, by evaluating the iconographic series, we study disputes over social imaginary of the new city, reinvented as negative utopia, the distopia Brasiliæ.

Keywords political cartoon, Careta magazine, popular music, liberal political culture

Deixemos entregues ao esquecimento e ao juízo da História os que não compreenderam e não amaram esta obra. (Juscelino Kubitschek, na inauguração de Brasília, 21/04/1960)

De nada valia o pio das aves de mau agouro da imprensa e de alhures, contra o ímpeto maravilhoso do trabalhador brasileiro, que acorreu de todos os cantos do país, especialmente do Norte, para erguer aquelas estruturas adiante do Tempo... (Vinícius de Moraes, no LP Brasília - Sinfonia da Alvorada, 1961)

\section{Maracangalha: humor \& política na fusão entre charge e música popular}

Em janeiro de 1957, em plena temporada pré-carnavalesca e após o início da construção da nova capital, a revista Careta (decano dos semanários humorísticos brasileiros) publicou em suas páginas uma divertida charge do caricaturista Théo, ${ }^{1}$ na qual, sob o olhar apreensivo e desconfiado de uma

1 Théo (Djalma Pires Ferreira, 1901-1980) era natural de Salvador (BA), tendo colaborado, dentre outras publicações, com D. Quixote, O Malho, Careta, Jornal do Brasil e O Globo. Em seu comentário sobre Théo, o crítico Herman 
matrona Burocracia, o presidente Juscelino Kubitschek, estilizado como retirante nordestino ("pioneiro" ou "candango"), se encaminha com trouxa no ombro para Brasília, cantarolando alegremente o conhecido samba de Dorival Caymmi (Figura 1). ${ }^{2}$

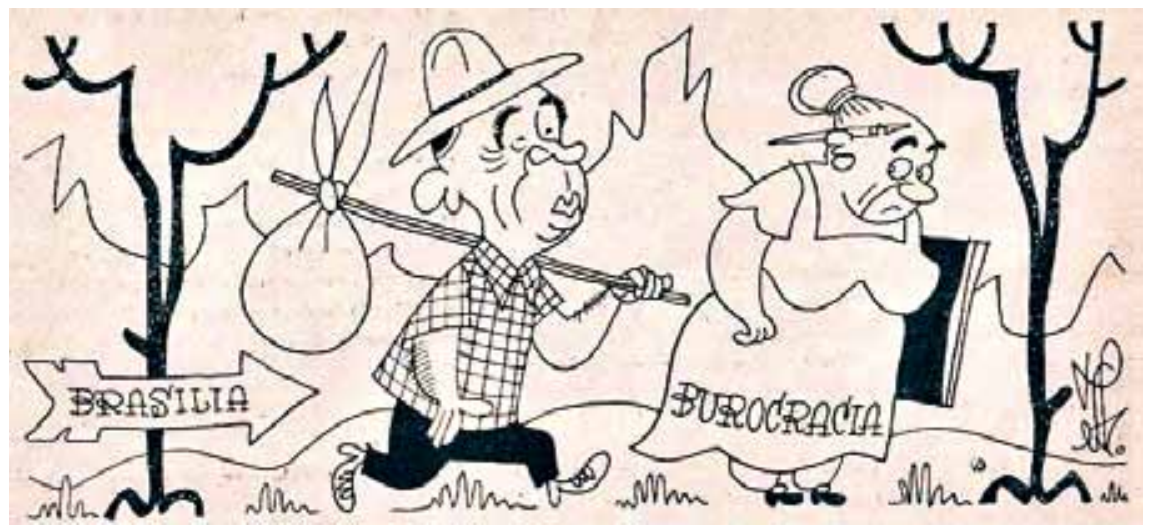

J. K. - Eu vou para MARACANGALHA, eu vou! Eu vou com chapéu de palha, eu vou, Se Anália não quiser ir eu vou só, eu vou só, eu vou só, mas eu vou!

Figura 1. THÉO. Sem título. Careta, Rio de Janeiro, ano XLIX, n.2.535, p.40, 26 jan. 1957.

Numa primeira leitura, a charge pode ser vista como uma bem humorada crítica à Anália burocracia, que estaria, por um lado, receosa de embarcar no projeto utópico de Brasília e dos "50 anos em 5", e, por outro, pesarosa em abandonar a boa vida já constituída na antiga capital federal, o Rio de Janeiro (Velhacap). O tema da resistência ao novo distrito federal (Novacap), aliás, fazia parte dos possíveis modos de recepção da charge de Careta, manifestos ainda por meio de outras canções: quer na apropriação e ressignificação politizada de um antigo sucesso carnavalesco ("Daqui não saio,/ daqui ninguém me tira,/onde é que eu vou morar?/O senhor tem paciência de esperar./Ainda mais com quatro filhos,/onde é que eu vou parar?"); ${ }^{3}$ quer na marchinha mudancista composta para o carnaval de 1958, em que o cantor Jorge Veiga tentava convencer a companheira, dizendo: "Está na

Lima destaca a "segurança do traço" e a "destreza do desenho", aliadas a "uma extraordinária capacidade de apreensão do detalhe fisionômico decisivamente característico, que lhe permitiria com o tempo tornar-se um dos nossos maiores caricaturistas políticos". Cf. LIMA, Herman. História da caricatura no Brasil. v.4. Rio de Janeiro: Livraria José Olympio Editora, 1963, p.1392.

2 CAYMMI, Dorival. Maracangalha [Samba]. In: __. Eu vou p'ra Maracangalha. S.I.: ODEON, 1957. 1 disco sonoro, 33 1/3 rpm. Lado A, faixa 1 (2 min $46 \mathrm{~s}$ ).

3 VOCALISTAS TROPICAIS. Daqui Não Saio [Marcha]. Paquito, Romeu Gentil [compositores]. [S.I.]: ODEON, 1949 1 disco sonoro, 78 rpm, lado A (2 min $49 \mathrm{~s}$ ). Para a identificação das músicas, gêneros, compositores e intérpretes, recorremos ao Arquivo Nirez, em Fortaleza/CE (Disponível em: <http://www.projetodiscodeceranirez.com.br/ index2.html> . Acesso em: 30 mar. 2011); além de sites especializados, como: Instituto Moreira Sales (Disponível em: <http://ims.uol.com.br/> . Acesso em: 16 abr. 2011); Dicionário Cravo Albin da MPB (Disponível em: < http:// www.dicionariompb.com.br>. Acesso em: 10 abr. 2011); Década de 1950 (Disponível em: <http://decadade50. blogspot.com>. Acesso em: 7 mai. 2011). 
hora, Emília,/é agora, Emília,/deixa o Rio,/vem comigo pra Brasília. (bis)/A ideia não é má,/nasceu de JK./Então vamos pra lá,/que vai ser um chuá, oi!" ${ }^{4}$ O historiador Herman Lima destaca que o aproveitamento de canções carnavalescas (ou não) para a elaboração de charges satíricas é um recurso bastante utilizado no período. ${ }^{5}$

Contudo, a interpretação não se esgota no tema da resistência à mudança, pois é possível agregar outros níveis de legibilidade. Para tanto, é preciso escapar da tentação de procurar o "sentido essencial" da charge ou reduzi-la à simples intenção subjetiva do autor. Ao contrário, nosso intento é analisar as relações entre a charge e as circunstâncias e condições em que foi produzida, ou seja, pensar o circuito de produção, circulação, migração, recepção e apropriação dessa imagem satírica. ${ }^{6}$ Dessa maneira, a investigação se volta para o cruzamento entre os significados e usos sociais da música Maracangalha e as formas de representação do presidente na revista Careta (formando uma série em que se complementam o visível, o legível e o musical). ${ }^{7}$

Primeiro, vejamos a canção, lançada em fins de 1956 e sucesso do carnaval de $1957 .{ }^{8}$ Ao analisar a recepção da crítica cultural à obra de Dorival Caymmi, a jornalista Stella Teresa Caymmi (neta do cantor e compositor) aponta a imediata associação feita entre a canção e projetos de cidades ideais, citando dois exemplos característicos:

Entre a Maracangalha cantada pela viola de Dorival e a Pasárgada louvada na lira de Manuel [Bandeira], o coração de Barnabé, brejeiro, balança. ${ }^{9}$

Platão imaginou a República, Campanela sonhou com a Cidade do Sol, James Hilton criou Shangri-La, Manuel Bandeira saiu-se com Pasárgada (...) Dorival

4 VEIGA, Jorge. Vamos pra Brasília [Marcha]. Átila Bezerra, Sebastião Gomes, Valdir Ribeiro [compositores]. Rio de Janeiro: Copacabana, 1958. 1 disco sonoro, 78 rpm, lado A (2 min 29 s). A indicação desta e de outras músicas é do site Projeto Memória. No perfil ufanista e laudatório, comenta-se que: "Para JK, cinco anos de mandato foram cinqüenta de brincadeiras e piadas, por vezes ofensivas. Nem por um minuto, perdeu o bom humor e a tolerância" (grifo nosso). Veremos que as reações do governo JK às críticas da oposição não foram tão simpáticas assim. Disponível em: <http://www.projetomemoria.art.br/JK/biografia/4_criticos.html>. Acesso em: 3 mai. 2011.

5 LIMA, Herman. História da caricatura no Brasil. v.4, p.1399.

6 Ulpiano Meneses propõe uma metodologia de análise de séries iconográficas, com o desafio de investigar a "vida pregressa" das imagens. Cf. MENESES, Ulpiano T. Bezerra de. Fontes visuais, cultura visual, História visual: balanço provisório, propostas cautelares. Revista Brasileira de História, São Paulo, v.23, n.45, p.11-36, 2003.

7 A análise das diretrizes da revista Careta, relacionando-a à cultura política liberal, será feita no segundo tópico deste artigo. Foram consultadas 244 edições, de janeiro de 1956 a outubro de 1960, totalizando pouco mais de 2.400 charges, das quais foram selecionadas 180 relativas à temática estudada. Foram pesquisados o acervo particular da profa. Adelaide Gonçalves (PPGH/UFC) e o acervo on-line da Biblioteca Nacional. Disponível em: $<$ http://objdigital.bn.br/acervo_digital/div_periodicos/careta/careta_anos.htm>. Acesso em: 20 mar. 2011.

8 Marcos Napolitano propõe umā metodologia de análise da música popular, articulando uma análise interna (letra, melodia, arranjo, intérprete e gênero) com uma análise contextual (processos de criação, produção, circulação, recepção e apropriação das canções). Nos limites deste artigo, abordaremos apenas algumas dessas dimensões. Cf. NAPOLITANO, Marcos. A história depois do papel (fontes audiovisuais). In: PINSKY, Carla B. (org.). Fontes Históricas. 2 ed. São Paulo: Contexto, 2006, p.254-273. E ainda: NAPOLITANO, Marcos. História \& Música: História cultural da música popular. 3 ed. Belo Horizonte: Autêntica, 2005, p.94-108.

9 COLUNA Rádio e TV. Correio da Manhã, Rio de Janeiro, 21/03/1956. Apud CAYMMI, Stella Teresa Aponte. O portador inesperado: a obra de Dorival Caymmi (1938-1958). Rio de Janeiro: Pontifícia Universidade Católica do Rio de Janeiro, 2006. (Letras, Dissertação de mestrado), p.90. 
Caymmi bolou um dia a sua Maracangalha e pra lá vai ele, de clássico uniforme branco, com ou sem Anália. ${ }^{10}$

Na mesma senda interpretativa, o poeta Antônio Risério afirma que o conjunto da obra de Caymmi (especialmente as canções praieiras de Itapuã) constitui uma "utopia de lugar", compondo "uma versão idealizada da Bahia". Já Maracangalha seria "a Pasárgada da chamada 'era desenvolvimentista", se convertendo, desde os anos 1950, numa "fantasia neo-romântica", atualização do mito edênico da Bahia, terra bela e lírica, festiva e sedutora. ${ }^{11}$

Mas não foi apenas a crítica especializada que se encantou com Maracangalha, pois a canção tornou-se um grande sucesso popular, sendo indicada pelo compositor Lamartine Babo como destaque do carnaval. ${ }^{12}$ Já o jornalista Oswaldo Miranda assinalou que:

O disco do baiano para a Odeon está vendendo muito e sua produção já se consagrou no assobio anônimo das ruas cariocas. De repente a cidade é sacudida por um samba bom, um samba muito brasileiro que ganha fácil o assobio das ruas, a repetição nos programas de calouros, a consagração imediata. ${ }^{13}$

Além dos aspectos apontados, o Barnabé anônimo das ruas, praças e cidades do país foi seduzido porque a canção se associava explicitamente a um dos maiores símbolos do imaginário social brasileiro, o malandro. Uma reportagem especial da revista Manchete procurou "saber como nasceu em Caymmi a inspiração do samba", esclarecendo que "o poeta das praias da Bahia" teria contado numa roda de amigos que:

Nos bons tempos de boêmia em Salvador, tinha um bom companheiro, que, apesar dos seus poucos recursos, sustentava duas famílias. Para isso, dava um murro danado, vendendo mil e uma bugigangas, dia e noite, entre uma pinga e outra. Como negociava com gente de Maracangalha, toda vez que queria passar alguns dias com a segunda mulher (viviam ambas em Salvador), dizia para a primeira: "Eu vou pra Maracangalha, mulher". ${ }^{14}$

Malandragem, boêmia e amantes: uma trinca irresistível. Assim, de forma sugestiva, Maracangalha logo se transformou em comercial de Ron

10 VASCONCELOS, Ary. O Cruzeiro, Rio de Janeiro, 04/08/1956, apud CAYMMI, Stella Teresa Aponte. O portador inesperado, p.90. O jornalista e crítico Ary Vasconcelos participou do grupo dos "folcloristas urbanos", organizados na Revista de Música Popular (1954-1956), que afirmou a ideia de uma "época de ouro" ligada à "tradição" do samba (anos 1930), reconhecido como manifestação nacional e autêntica. Cf. NAPOLITANO, Marcos e WASSERMAN, Maria Clara. Desde que o samba é samba: a questão das origens no debate historiográfico sobre a música popular brasileira. Revista Brasileira de História, São Paulo, v.20, n.39, p.177-178, 2000

11 RISÉRIO, Antônio. Caymmi: uma utopia de lugar. São Paulo/Salvador: Perspectiva/COPENE, 1993, p.108-110 e p.123. (Debates, v.253).

12 O Globo, Rio de Janeiro, 04/02/1957, apud CAYMMI, Stella Teresa Aponte. O portador inesperado, p.91.

13 MIRANDA, Oswaldo. Última Hora, Rio de Janeiro, 18/10/1956. Apud CAYMMI, Stella Teresa Aponte. O portador inesperado, p.91

14 ALENCAR, Inácio de. Afinal, que é Maracangalha? Manchete, Rio de Janeiro, n.250, p.41-44, 02/02/1957. 
Merino (embora a bebida "esteja mais para rumba do que para samba", ironiza Stella Caymmi). Na foto da propaganda, o baiano Dorival está recostado caprichosamente na rede, dedilhando ao violão que iria, "mas só com Ron Merino". O texto publicitário acrescenta que "Se ela não quiser ir, vá com Ron Merino... mas não vá só!". A representação de do/ce far niente (vadiagem), do malandro embalando-se na rede preguiçosa, acompanharia o compositor por toda a vida. ${ }^{15}$

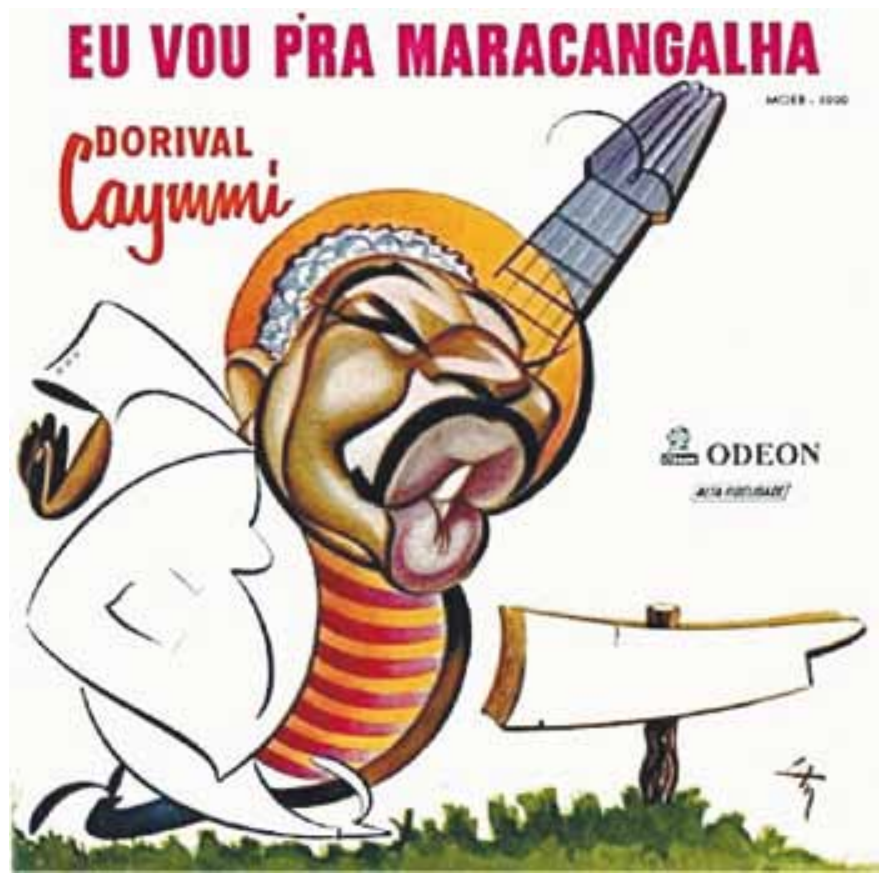

Figura 2. LAN. Capa-caricatura do LP Eu vou p'ra Maracangalha. S.I.: Odeon, 1957.

Outro elemento de conjunção entre Maracangalha e malandragem foi a caricatura de capa do disco, em que os traços curvilíneos do ítalo-carioca Lan esboçam um beiçudo e simpático mulato Dorival, de paletó branco, camisa estilo marinheiro, violão às costas, seguindo rumo à cidade ideal (Figura 2) ${ }^{16}$ A caricatura conferiu nova visibilidade ao topos malandro da partida, tema consagrado anos antes no samba-choro cantado por Carmem Miranda: "Vestiu uma camisa listada e saiu por aí/Em vez de tomar chá com torrada, ele tomou parati. [agora seria Ron Merino]/Levava um canivete no

15 CAYMMI, Stella Teresa Aponte. Dorival Caymmi: o mar e o tempo. São Paulo: Editora 34, 2001, p.344.

16 Lanfranco Aldo Ricardo Vaselli Cortellini Rossi Rossini, ou simplesmente Lan, trabalhou nos diários Última Hora, Jornal do Brasil e O Globo. Cf. A CARIOQUICE do grande Lan. Jornal da ABI - 170 anos da caricatura no Brasil, Rio de Janeiro, n.322 (edição extra), p.20-21, out. 2007. Disponível em: < http://www.abi.org.br/jornaldaabi/Suplemento_Especial_Caricatura-2007.pdf > . Acesso em: 17 jan. 2011. 
cinto e um pandeiro na mão./E sorria quando o povo dizia: sossega leão, sossega leão". ${ }^{17}$

Por um acaso da história, o momento de surgimento e consagração da malandra Maracangalha coincide com a campanha nacional de recrutamento (pela imprensa, cinema, música, rádio e TV) dos "pioneiros", "desbravadores" e "bandeirantes modernos" para a construção da nova capital. Tal campanha se organizava em torno da ideia de que a Operação Brasília seria um mecanismo de construção de uma nova identidade nacional e promoção do desenvolvimento econômico, visando justificar simultaneamente a Novacap e as políticas do governo federal (Plano de Metas). Nessa busca de legitimidade, foram utilizados argumentos de diferentes sentidos, tanto históricos (uma "nova fundação do Brasil", a continuidade das "bandeiras", o "sonho dos inconfidentes", o "ideal republicano", a "ruptura com o passado" e o "salto para o futuro"), quanto míticos (o "sonho" de Dom Bosco, a simbologia cristã da cruz, a iconologia de fundação de cidades na antiguidade - de Roma, muito especialmente). ${ }^{18}$

Dessa forma, um topos heroico da partida estava no cerne da estratégia midiática do governo JK, que perfazia "um apelo a brasileiros de todas as regiões e origens sociais para que participassem de uma obra pública destinada a forjar a integração nacional". ${ }^{19}$ Uma exortação repetida também na música popular, com o samba Adeus, Mangueira (do filme-musical É de Chuá):

Juscelino me chamou,/Eu vou morrer de saudade, mas vou.../O hômi tá chamando.../Adeus, Mangueira,/Adeus, meu Vigário Geral/Adeus, meu samba./ Adeus, capital federal/Brasília me chamou pra trabalhar,/seu doutor, dá licença, minha gente eu vou levar. ${ }^{20}$

No número musical, samba e malandragem se reúnem na disposição mudancista, com a Rainha do Carnaval a fazer uma paradoxal convocação geral para o trabalho ("o hômi tá chamando"), seguida por sua corte de passistas, músicos e intérpretes. Logo, a música, a batucada e a dança são acompanhadas por golpes de capoeira, jogados por Grande Otelo e Ankito, que simulam um "corta-capim" e um "rabo-de-arraia". A chanchada

17 MIRANDA, Carmem. Camisa Listada [Samba choro]. Assis Valente [compositor]. S.I.: ODEON, 1937. 1 disco sonoro, $78 \mathrm{rpm}$, lado B (3 min $5 \mathrm{~s})$. Sobre a trajetória do malandro, desde sua invenção como "emblema da brasilidade" até sua "desconstrução" e "desvanecimento", cf. SOUZA, Jessé. As metamorfoses do malandro. In: CAVALCANTE, Berenice et al. (orgs.). Decantando a República: inventário histórico e político da canção popular moderna brasileira. v.3. Rio de Janeiro/São Paulo: Nova Fronteira/Fundação Perseu Abramo, 2004, p.39-50.

18 Nos limites deste artigo, não poderemos nos deter neste ponto. A bibliografia crítica dos mitos e simbologias de Brasília é vasta: HOLSTON, James. A cidade modernista: uma crítica de Brasília e sua utopia. São Paulo: Companhia das Letras, 1993; VESENTINI, José William. A capital da geopolítica. São Paulo: Ática, 1986; BICCA, Paulo. Brasília: mitos e realidades. In: PAVIANI, Aldo. (org.). Brasília, ideologia e realidade: espaço urbano em questão. São Paulo: Projeto, 1985, p.101-133; QUEIROZ, Ana. O Plano Piloto de Brasília e a busca da cidade ideal: utopia, arte e mitologia. ArtCultura, Uberlândia, v.9, n.14, p.157-167, jan-jun 2007.

19 HOLSTON, James. A cidade modernista, p.207.

20 TRIO DE OURO (Herivelto Martins, Raul Sampaio, Lourdes Bittencourt). Adeus, Mangueira [Samba]. Herivelto Martins, Grande Otelo [compositores]. São Paulo: RCA Victor, 1958. 1 disco sonoro, 78 rpm, lado B (1 min $58 \mathrm{~s}$ ). Trilha sonora da chanchada É de Chuá (Direção de Victor Lima, 1958). 
presta uma dupla homenagem: à escola de samba Mangueira e à Novacap, fazendo a "saudação do morro numa promessa a favor do planalto", no comentário do diplomata Osvaldo Orico. ${ }^{21}$ Do nosso ponto de vista, trata-se de autêntico samba-exortação, cumprindo função política similar ao samba-exaltação do Estado Novo, qual seja, legitimar o projeto nacionaldesenvolvimentista do governo Kubitschek. ${ }^{22}$

Voltando à charge Maracangalha (Figura 1), podemos afirmar que, ao realizar a fusão satírica das duas versões do topos da partida, com predomínio do ponto de vista boêmio e consequente rebaixamento do tom épico, o desenho de Théo provocou um curto-circuito das representações, na medida em que as presenças da desconfiada Anália burocracia e do pioneiro-malandro JK promovem uma ácida crítica da "aventura" e "loucura" da nova capital, defendida no discurso oficial como ato racional de planejamento, trabalho e vontade. Assim, o projeto da nova civitas seria resultante da esperteza do governante que, por meio desse subterfúgio, buscava escapulir do enfrentamento das questões nacionais (as vetustas madames Crise Econômica e Vida Cara, ao lado da robusta Inflação e da senhora Greve, sempre de braços cruzados; Figura 3), afundando ainda mais o país com os gastos extraordinários de construção.

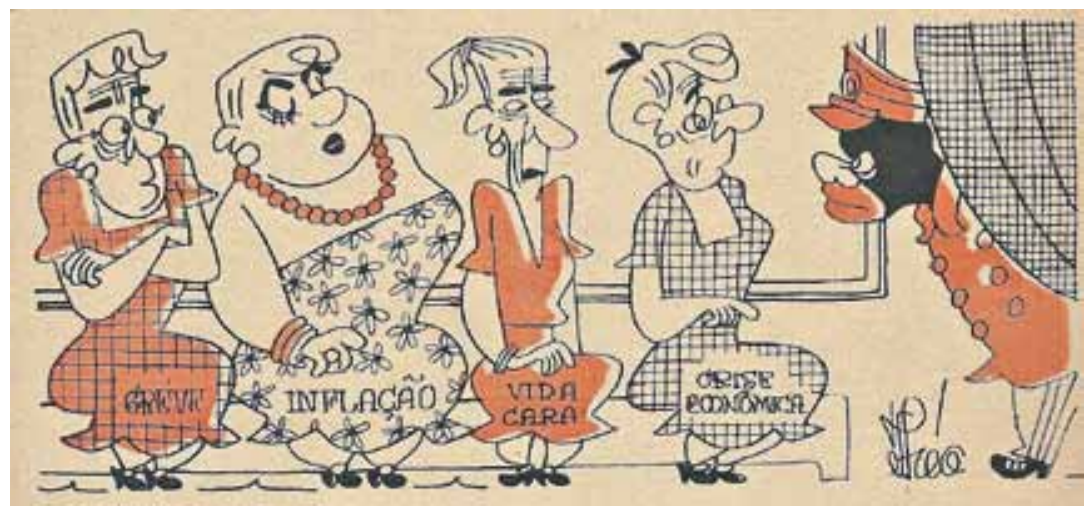

- Vosmicês "tão" perdendo seu tempo. Ele "tá" passeando em BRASÍLIA e acha muito chato "atendê" as senhoras!

Figura 3. THÉO. Sem título. Careta, Rio de Janeiro, ano L, n.2.579, p.28, 30 nov. 1957.

Dessa maneira, segundo a revista de humor, o absenteísmo seria uma marca registrada de JK, defeito exemplificado pela "mania ambulatória", de estar sempre viajando a bordo do avião Viscount, razão pela qual foi apeli-

21 ORICO, Osvaldo. Brasil, capital Brasília. Rio de Janeiro: IBGE, 1958, p.174. O livro foi pensado como um laudatório "cartão de visitas" da Novacap, apresentada ao mundo pelo jornalista e diplomata Osvaldo Orico (da Academia Brasileira de Letras), que compunha o time dos "ghost-writers" de JK, ao lado de outros escritores, como Josué Montello, Augusto Frederico Schmidt e Ciro dos Anjos. Foi apelidado por Careta de "o maior camelô de Brasília", enquanto Augusto Frederico Schmidt era "o poeta dos supermercados".

22 Retomaremos esta ideia no último tópico do artigo, sobre a polêmica musical de Brasília. 
dado de ĺcaro, o presidente-voador. Tal "governo aéreo" (com "a cabeça no mundo da lua") foi diagnosticado pelo professor Napoleão L. Teixeira como um caso de dromomania, a "verdadeira impulsão obsessiva, irresistível, a fugir, viajar. Escapismo, running away, mas fuga, ao cabo de tudo". ${ }^{23}$

Não por acaso, tais ideias-imagens reaparecem em outra charge, de refiguração do universal personagem de Miguel de Cervantes (Figura 4), na qual a insensatez do estropiado cavaleiro JK de La Mancha é estendida a todo o governo, na pessoa de José Maria Sancho Pança Alkmin (Ministro da Fazenda). Com um olhar entre espantado e intrigado, o Jeca (personagem símbolo do brasileiro na Careta) desfere uma frase mordaz, que bem poderia ter sido dita por Anália burocracia diante do malandro-pioneiro. ${ }^{24}$

A estratégia de ridicularização e desmoralização da persona presidencial se estendeu a outros aspectos de sua vida pública e privada. No âmbito oficial, o semanário denunciou constantemente vários casos de apadrinhamento e nepotismo, como a indicação de parentes da primeira-dama para assumir cargos públicos ou a titularidade de rendosos cartórios em Minas e no Rio de Janeiro. Já na esfera privada, ganhou relevo a personalidade boêmia de JK, especialmente as festas com artistas, o gosto pela dança (daí o apelido de Nonô pé de valsa) e as diversas amantes.

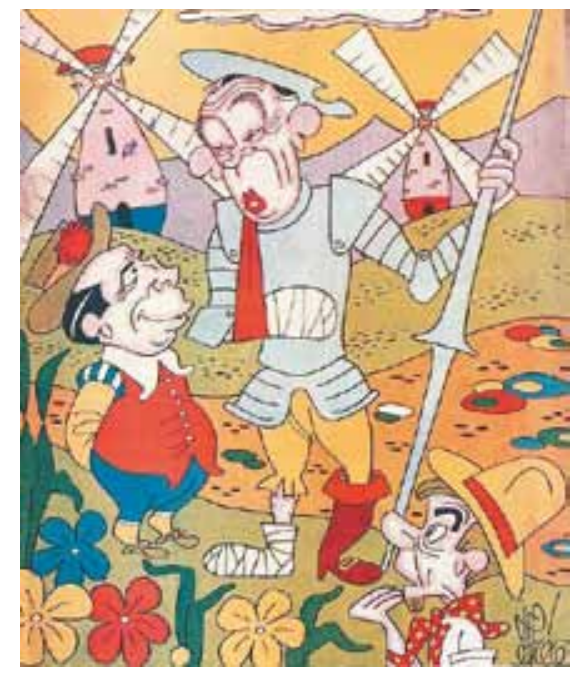

JECA - Meu azar é que esse Sancho Pança, em vez de ser um sujeito de bom senso, sofre da mesma loucura do D. Quixote!

Figura 4. THÉO. Capa. Careta, Rio de Janeiro, ano L, n.2.567, 07 set. 1957.

23 TEIXEIRA, Napoleão L. A mania ambulatória presidencial e os males que acarreta. Careta, Rio de Janeiro, ano L, n.2.584, p.4-5, 04/01/1958. O autor era Catedrático da Universidade do Paraná, especialista em psicologia e psiquiatria forense, com várias obras publicadas nessas áreas.

24 Sobre o personagem Jeca Tatu, desde sua criação por Monteiro Lobato (Urupês, 1918) até a apropriação e reinvenção pelo humor gráfico, numa mistura de malícia e (falsa) ingenuidade, cf. MALTA, Márcio José Melo. Jeca na Careta, charges e identidade nacional. Rio de Janeiro: Universidade Federal do Rio de Janeiro, 2007. (Ciência Política, Dissertação de mestrado). 
Apontado como "desfrutável" e dado aos prazeres carnais, JK foi alvo privilegiado de fofocas maledicentes, muitas delas envolvendo misses, a exemplo de dois casos citados pelo jornalista Bianor Penalber. No primeiro, o colunista de Careta menciona o interesse de Juscelino pelas medidas de busto, coxas e quadris de Miss Brasília 1959, a qual saiu do encontro comentando, "sem ironia": "Nem parece o presidente da República". Já no segundo episódio, mais grave, o articulista revela aos leitores a "cacofonia presidencial", pois, em êxtase diante da beleza de Miss Brasil 1960 (a carioca e botafoguense Gina MacPherson), JK saiu-se com uma frase "atentatória dos bons princípios morais" (para alguns) ou "explosão do subconsciente" (para outros): "Vá, Gina, e coloque bem alto, no estrangeiro, o nome do nosso Brasil". 25

Diante de tais circunstâncias, não é de estranhar que a campanha oficial em prol da construção da Novacap envolvesse também a defesa da imagem pública de JK e, no limite, chegasse às raias do culto à personalidade. Dessa maneira, na semana seguinte à publicação da charge Maracangalha, a revista Manchete (entre as de maior circulação no país) foi às bancas com uma incomum foto de capa, na qual Juscelino, bem vestido e sentado de maneira severa, olha fixamente para o relógio no braço esquerdo, numa "áspera impaciência diante do tempo", atitude típica de quem está com pressa e muito ocupado trabalhando. ${ }^{26}$

Na reportagem de Manchete (um balanço do primeiro ano de governo), além da justificativa dos rumos da política econômica, da Operação Brasília e das viagens para "estimular in loco as necessidades e realizações nacionais", ganhou destaque o perfil do presidente, apresentado como um homem corajoso e determinado, mas ao mesmo tempo pacato, informal e de hábitos simples. Bom pai de família, JK tinha nas figuras da mãe e da esposa suas "duas grandes admirações", além de ter deixado de dançar "por falta de tempo"; contudo, "não perdeu o bom humor e ainda faz blague", sendo "bem informado desde os mais secretos bastidores políticos até a última charge que o jornal publica" (grifo nosso). ${ }^{27}$ A matéria se encerrou com o depoimento de José Moraes, secretário de imprensa de JK há mais de dez anos, que o descreveu em termos modernistas:

Chego a ver JK como uma máquina monstruosa, um mecanismo todo metálico, que não deixa ninguém parar, porque ele não pára... É tudo - espírito e coração

25 PENALBER, Bianor. Cacofonia presidencial. Careta, Rio de Janeiro, ano LIII, n.2.718, p.18, 30/07/1960.

26 Sobre o apoio de Adolpho Bloch (presidente do grupo editorial Bloch/Manchete) ao governo Juscelino, conferir a entrevista com o jornalista Murilo Melo Filho. In: BRASíLIA, capital da controvérsia: a construção, a mudança e a imprensa. Rio de Janeiro: Secretaria Especial de Comunicação Social - Prefeitura da Cidade do Rio de Janeiro, 2002, p.52-3. (Cadernos da Comunicação, Série Memória, v.5).

27 TAVARES, Marcelo Coimbra. Confidencial: JK julga a si mesmo. "Venci porque nunca tive medo". Manchete, Rio de Janeiro, n.250, p.10-13, 02/02/1957. 
- nas 24 horas do dia, voltados para uma obsessão: os problemas do Brasil. Não há maior paixão, maior veemência. Vive e sonha problemas do Brasil e às vezes, tenho a impressão de que está falando sozinho. Aguço o ouvido, e está mesmo: problemas do Brasil. ${ }^{28}$

\section{Careta: ridendo facit civitas (rindo, inventa-se a cidade)}

Ao desvelar as visões e estratégias conflitantes em torno da mudança da capital federal e da legitimação do governo JK, a análise da série iconográfica de Careta possibilita apreender as acirradas disputas políticas que marcaram um período usualmente denominado pela memória social (e parte da historiografia) de "Anos Dourados". Conforme salienta Flávia Biroli, essa representação do governo JK foi reforçada pelo fato de que esse momento de "vigência da democracia constitucional" ficou "espremido diante das fronteiras da violência de duas ditaduras (a do Estado Novo e a do pós-64)", de modo que as imagens predominantes fortalecem uma "suposta homogeneidade" advinda da associação entre "democracia, liberdade, desenvolvimento ou esperança" como "identificadores da atmosfera" nacional. ${ }^{29}$

Eleito em outubro de 1955 com apenas 36\% dos votos (pela coligação PSD-PTB), Juscelino teve sua posse impugnada e ameaçada pela oposição militar e civil (UDN), somente assumindo a presidência após o chamado "contragolpe de 11 de novembro", desfechado pelo então Ministro da Guerra, o general Henrique Teixeira Lott, que mobilizou tropas do Exército para estabelecer o Estado de Sítio e garantir a posse. Por conseguinte, desde os primórdios, o governo JK sofreu forte oposição, mantendo-se no poder através de um complexo equilíbrio de forças, que envolvia uma instável base de apoio político e social do Congresso Nacional, da imprensa, dos sindicatos e da população em geral, além da sustentação militar, por meio dos generais Henrique Lott (mantido no Ministério da Guerra) e Odílio Denis (comandante da Zona Militar Leste/RJ).

Segundo a oposição, o general Henrique Lott tornou-se a "eminência parda" do governo de seu "afilhado-satélite", Juscelino Kubitschek de Oliveira. Submetido à "tutela militar", o presidente foi rebatizado de JK Lott - cacófato e imagem de pensamento sintetizados de forma irônica pelo lápis de Théo, ao projetar nas sombras o "verdadeiro" poder por trás do presidente (Figura 5).

28 MORAES, José. Como vemos JK. Manchete, Rio de Janeiro, n.250, p.17, 02/02/1957.

29 BIROLI, Flávia. Liberdade de imprensa: margens e definições para a democracia durante o governo de Juscelino Kubitschek (1956-1960). Revista Brasileira de História, São Paulo, v.24, n.47, p.213-40, 2004. 


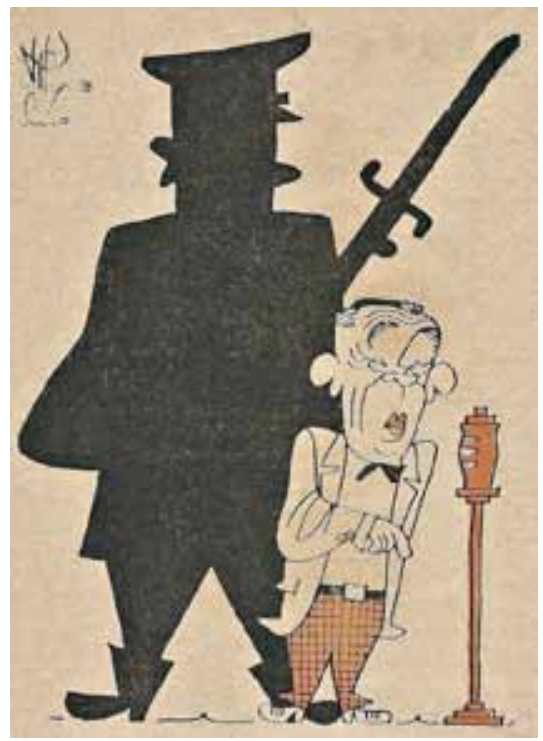

J. K. - Ai daquele que ameaçar o poder civil!

Figura 5. THÉO. Sem título. Careta, Rio de Janeiro, ano L, n.2.566, p.4, 31 ago. 1957.

Da mesma forma, a construção de Brasília (meta-síntese do Plano de Metas) teve de início pouca aceitação social, recebendo acerbas críticas da imprensa. Em janeiro de 1958, uma pesquisa IBOPE (realizada em cinco cidades: Rio de Janeiro, São Paulo, Porto Alegre, Recife e Salvador) apontou que apenas $21 \%$ dos entrevistados estavam de acordo com a Operação Brasília (a rápida construção e mudança), enquanto o índice de oposição chegava a 58,6\%. Segundo analisa a historiadora Vânia Moreira, "embora Brasília já fosse naquele momento um imenso canteiro de obras em plena atividade, existia uma oposição ao projeto bastante intensa e radical". 30 Contudo, em dezembro, outra rodada de pesquisas, com universo mais amplo (10 cidades: as citadas, mais Curitiba, Fortaleza, Belo Horizonte, Campinas e Santos), indicou uma "nova tendência da opinião pública", "mais simpática à ideia mudancista", com 29,3\% dos entrevistados apoiando uma mudança rápida; 30,8\% defendendo a mudança gradual; e 27,5\% ainda totalmente contrários.

Apenas às vésperas da inauguração, em março de 1960, a proposta chegou a $74 \%$ de apoio popular, com $24 \%$ de oposicionistas (entretanto, a pesquisa se restringiu ao Rio de Janeiro). Assim, conclui Vânia Moreira, mesmo limitadas, tais pesquisas ajudam "a desmistificar a ideia de 'consenso'

30 MOREIRA, Vânia Maria Losada. Brasília, a construção da nacionalidade: um meio para muitos fins (1956-1961). Vitória: EDUFES, 1998, p.70. A autora analisa em detalhe essa e outras pesquisas do IBOPE. 
e 'euforia' em torno da construção de Brasília", apresentando-a como "um fato discutível e negociável, não um fato consumado"; portanto, "a tendência de aceitar Brasília cresceu com o tempo". ${ }^{31}$ Do exposto, verifica-se que se travava uma verdadeira "guerra de imagens", buscando a formação das consciências e disputando ícones, ideias e valores no interior da sociedade brasileira. Conflito simbólico, envolvendo os mais diversos grupos políticos e sociais, no qual a revista Careta estava profunda e radicalmente inserida, por meio de seus editoriais e artigos, piadas e charges.

Criada em 1908, pelo inovador Jorge Schmidt, Careta é considerada pelo historiador Nélson Werneck Sodré como a mais característica das revistas ilustradas brasileiras da primeira metade do século XX (ao lado de $O$ Malho, Fon-Fon, O Tico-Tico), tornando-se "popular como nenhuma outra, encontrada nos engraxates, barbeiros, consultórios, etc.". ${ }^{32}$ Combinando jornalismo opinativo, literatura (crônica, conto e poesia) e humor gráfico (charge e caricatura), o semanário estava presente em todo o território nacional (capitais e maiores cidades, pelas mãos da Fernando Chinaglia Distribuidora S.A.), sendo facilmente encontrado nas bancas e livrarias dos principais logradouros, além de contar com serviço de assinatura pelos correios. Numa crônica, o jornalista Adenor Filho forneceu uma sugestiva indicação do processo de circulação e das formas de sociabilidade em torno do humorístico:

\begin{abstract}
Rendo a homenagem do meu respeito a todos os barbeiros deste país, por serem colaboradores espontâneos de uma causa muito alta: a luta contra a corrupção, a malandragem administrativa, a safadeza política, o filhotismo e demais processos malignos da desgraça nacional. Porque os barbeiros do Brasil, há mais de cinqüenta anos, se tornaram os tradicionais intermediários entre a revista "Careta" e o povo brasileiro (...) Pode haver barbeiros situacionistas, que votaram nos candidatos do governo. Mas serão minoria, com certeza, neste vasto e generoso País. Não seriam eles os veículos da verdade, os arautos da liberdade, os defensores da legítima democracia (...) - se não vislumbrassem na "Careta", todas as semanas, aquilo que a "Careta" tem sido sempre: o balancete semanal e real da conjuntura brasileira. ${ }^{33}$
\end{abstract}

Em seu estudo clássico, Herman Lima assinala "o imenso prestígio que sempre desfrutou Careta, não somente nas classes intelectuais do país, como no seio do povo", mantendo por bastante tempo o "prestígio paradoxal que a fazia disputada pelos fregueses de engraxates e barbeiros e pela elite intelectual". ${ }^{34} \mathrm{Um}$ interessante depoimento nesse sentido foi

31 MOREIRA, Vânia M. L. Brasília, a construção da nacionalidade, p.72-3 e p.88

32 SODRÉ, Nélson Werneck. História da imprensa no Brasil. 4. ed. Rio de Janeiro: Mauad, 1999, p.302.

33 ADENOR FILHO. Diário do Comércio, São João Del Rei, MG, 08/10/1960, apud Careta, Rio de Janeiro, ano LIII, n.2.731, p.23, 29/10/1960.

34 LIMA, Herman. História da caricatura no Brasil. v.1, p.150 e 152. 
escrito pelo historiador e folclorista Luís da Câmara Cascudo, em crônica de evocação da morte e da memória do pai:

- Descansando, Papai Cascudo?

- É verdade, minha filha...

Minha mulher entrou para a sala de banhos, lavou as mãos. Quando voltou, o velho coronel Francisco Cascudo estava morto, sereno, como se dormisse. Debaixo da rede, entreaberta pelo vento, estava a CARETA, revista preferida, leitura fiel desde 1908. Minutos antes de morrer tivera-a diante dos olhos (...) Criei-me vendo e folheando as revistas "clássicas" do meu tempo, O MALHO, político, O TICO-TICO, infantil, a CARETA, variada, espirituosa, com as caricaturas da vida social e também destinada à higiene mental do riso. Sim, e o FON-FON, onde já havia informação literária. A CARETA acompanhou-me cinqüenta anos (...) Meu pai comprava-a na Livraria Cosmopolita, do major Fortunato Aranha e, nos últimos anos, na Agência Pernambucana, de Luiz Romão (...) Agora, meses e meses, não tenho oportunidade de rever a revista de minha meninice, infância e madureza (...) Há tanto tempo que não via CARETA. Levou-me para a vida de meu pai, trazendo-a enrolada, saboreando-a, espalhando suas graças, rindo, como ela sabia rir, das caricaturas, dos sueltos. ${ }^{35}$

Uma das razões do sucesso editorial de Careta foi contar desde o princípio com a colaboração do traço inconfundível de J. Carlos (considerado o maior dos caricaturistas brasileiros), que nela trabalhou em duas fases (de 1908 a 1922 e de 1935 até a morte, em 1950). ${ }^{36}$ Além de J. Carlos e Théo, outros nomes consagrados do desenho de humor colaboraram com a revista, como Raul (Pederneiras), Calixto (Cordeiro), (Alfredo) Storni, Seth (Álvaro Martins), Yantok (Cesarino Max) e Vasco Lima. ${ }^{37}$ A partir de 1935 , com a morte do fundador, a revista passou a ser administrada por seu filho, Roberto Schmidt (o Bob dos editoriais), tendo enfrentado sucessivos problemas com a censura do DIP e as restrições à importação de papel durante o Estado Novo.

Uma vez derrubada a ditadura, Careta adotou uma tônica marcadamente política em sua linha editorial e humorística (com as penas de J. Carlos e Théo), assumindo a defesa do ideário liberal, bem como a crítica a Vargas e à herança autoritária do Estado Novo (1937-45), o qual continuaria se reproduzindo nos governos do general Eurico Gaspar Dutra (1946-51), Getúlio Vargas (1951-54) e Juscelino Kubitschek (1956-61). Com esse propósito, a revista se aproximou dos posicionamentos do maior partido de oposição ao varguismo, a UDN (União Democrática Nacional), muito

35 CASCUDO, Luís da Câmara. Ata diurna. A República, Natal, RN. Apud: Careta, Rio de Janeiro, ano LIII, n.2.727, p.18, 01/10/1960.

36 Sobre o talento extraordinário de J. Carlos (João Carlos de Brito e Cunha, 1884-1950), cf. LIMA, Herman. História da caricatura no Brasil. v.3, p.1070-1125. O desenhista sofreu um acidente vascular cerebral (AVC), trabalhando em sua prancheta na redação de Careta, morrendo no dia 02 de outubro de 1950, véspera das eleições presidenciais.

37 BALBIO, Marcelo. Careta: a cara alegre do Rio. Revista de Comunicação, Rio de Janeiro, ano 8, n.28, p.17, abr. 1992. 
embora com diferenças e fortes críticas pontuais (especialmente quando políticos udenistas decidiam fazer alianças com o governo).

Tal comprometimento se expressou através do apoio às candidaturas presidenciais do Brigadeiro Eduardo Gomes (1945 e 1950), de Juarez Távora (1955) e de Jânio Quadros (1960), formando ao lado de órgãos da chamada "grande imprensa" (O Estado de São Paulo, O Globo, Correio da Manhã, Tribuna da Imprensa), de jornais estaduais (O Combate no Maranhão, Jornal do Povo em Goiás) e de outros semanários (Libertação no Piauí, Maquis no Rio de Janeiro). Analisando O Estado de São Paulo, Maria Victoria Benevides cita comentário do banqueiro e político Herbet Levy, o qual, refutando a ideia de que a UDN possuía um jornal próprio, O Estadão, dizia, ao contrário, que "O Estado é que tem um partido, a UDN" ${ }^{38}$ Parafraseando, poderíamos dizer que a Careta tinha (quase sempre) um partido, a UDN.

Na rede de sustentação da política udenista, devem-se incluir os espaços abertos no rádio e na televisão. A força desse dispositivo de mídia se revelou extremamente eficaz em diferentes conjunturas, como, por exemplo, na crise política do 2 o governo Vargas, com destacada atuação do jornalista Carlos Lacerda, durante a CPI do jornal Última Hora (1953) e a crise de agosto de 1954, momento em que Lacerda teve amplo acesso aos microfones da Rádio Globo (de Roberto Marinho) e da TV Tupi (de Assis Chateaubriand). ${ }^{39}$

Nessas circunstâncias, podem-se contextualizar as iniciativas do governo JK em relação ao controle e à censura da imprensa (geralmente "esquecidos" por muitas análises dos "Anos Dourados"). A começar pela fracassada tentativa de reformar a Lei de Imprensa (1953), com o envio ao Congresso Nacional de novo projeto (em outubro de 1956), sob a justificativa da "defesa da segurança do Estado e do sistema constitucional em face da imprensa subversiva e fomentadora de desordens", pois haveria "a facilidade ou a irresponsabilidade na prática de injuriar, difamar ou caluniar". ${ }^{40}$ Simultaneamente, o Ministério da Viação e Obras Públicas editou a Portaria no 899/1956, "buscando regular politicamente o conteúdo veiculado por rádio e televisão", sob a ameaça de suspensão ou mesmo rescisão da concessão. ${ }^{41}$ Tal norma estabelecia a proibição de veiculação de "anedotas maliciosas", "gracejos picantes" ou "quaisquer manifestações" que implicassem na "subversão da ordem pública", na "animosidade entre as classes armadas, ou delas contra as instituições civis", na "incitação à

38 BENEVIDES, Maria Victoria de Mesquita. A UDN e o udenismo: ambigüidades do liberalismo brasileiro (1945-1965). Rio de Janeiro: Paz e Terra, 1981, p.229.

39 O jornal Última Hora foi acusado de receber empréstimos privilegiados do Banco do Brasil para defender o governo Vargas. Cf. CALABRE, Lia. Rádio e política: o caso do Parlamento em Ação. In: NEVES, Lúcia M. B. P., MOREL, Marco e FERREIRA, Tânia Maria B. da C. (orgs.). História e imprensa: representações culturais e práticas de poder. Rio de Janeiro: DP\&A/FAPERJ, 2006, p.401-413.

40 A mensagem presidencial ao Congresso Nacional foi publicada no jornal O Estado de São Paulo, 10/10/1956, p.5, apud BIROLI, Flávia. Liberdade de imprensa, p.221.

41 BIROLI, Flávia. Liberdade de imprensa, p.226. Mais adiante, veremos como a censura será também aplicada à música popular. 
desobediência coletiva" ou ainda na "injúria ou desrespeito às autoridades constituídas". 42

Batizados de "Projeto Rolha", "Lei do Arrocho" ou "Portaria Rolha", tais dispositivos foram interpretados como um mecanismo para calar a oposição udenista e, especialmente, Carlos Lacerda, considerado um dos principais adversários, em função dos episódios de crise açulados pelo Corvo ${ }^{43} \mathrm{~A}$ censura tornou-se um dos alvos prediletos das charges de Théo (Figura 6), ironizando a desproporção de recursos entre a oposição, amordaçada e acusada de "abusar", e o governo do cínico JK, com a imprensa "debaixo do braço" para fazer a ufanista publicidade oficial-pessoal.

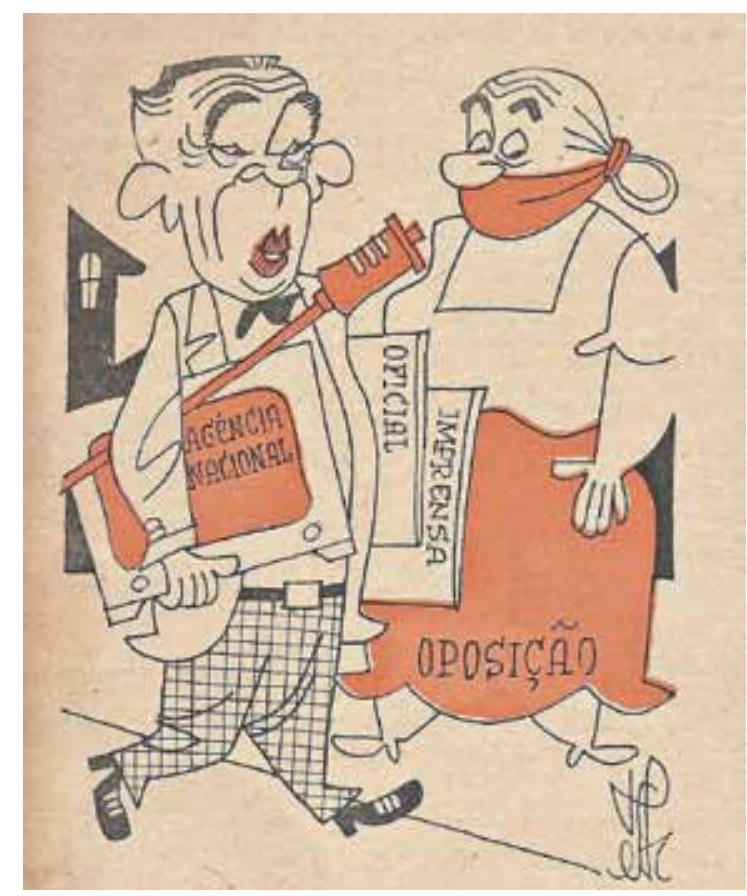

J. K. - Você está abusando, por que eu não tenho tempo nem meios de fazer a minha propaganda pessoal!

Figura 6. THÉO. Sem título. Careta, Rio de Janeiro, ano L, n.2.566, p.40, 31 ago. 1957.

42 Artigo 1ำ da Portaria n.899, de 8 de outubro de 1956. Apud LINS, Bernardo E. Da censura de costumes à censura política: o episódio da "portaria rolha". In: XII CONGRESSO DE CIÊNCIAS DA COMUNICAÇÃO NA REGIÃO CENTRO-OESTE, 2010, Goiânia. Anais... Goiânia, 2010, p.8.

43 O apelido de Corvo foi usado pela primeira vez no jornal Última Hora, em caricatura de Lan e idéia de Samuel Wainer (25/05/1954). A charge referia-se aos usos políticos do assassinato do jornalista Nestor Moreira, vítima de brutalidade policial. A ave de mau agouro (lembrada por Vinícius de Moraes) caiu bem na imagem de quem vivia a cabalar conspirações contra presidentes da República. Cf.: ROSE, R. S. Uma das coisas esquecidas: Getúlio Vargas e controle social no Brasil (1930-1954). São Paulo: Companhia das Letras, 2001, p.206 e fig.60. 
A revista combateu ainda a cooptação de órgãos de mídia pelo governo (através de publicidade paga e da concessão de financiamentos), além de denunciar a elevação de impostos sobre insumos e matérias-primas (tintas e papel) com o objetivo de inviabilizar financeiramente a "imprensa limpa". Ao analisar os efeitos da lei no 3.244, de 14 de agosto de 1957, que aumentava o imposto de importação de papel, o editorial de Bob foi categórico em seus delineamentos:

O artigo 50 da lei 3244 é, portanto, arma apontada contra os poucos órgãos honestos da imprensa brasileira, aqueles raros jornais e revistas que se recusaram até hoje a, se não aderir, ao menos calar ante o descalabro que têm sido os últimos governos e principalmente o atual. Dessa imprensa limpa sobressaem-se a "Tribuna da Imprensa" [de Carlos Lacerda] e "Careta" no Rio de Janeiro, e o magnífico "Estado de São Paulo", na capital paulistana. Quer dizer: os melhores órgãos das duas maiores cidades do país serão as grandes vítimas da grande torpeza. Não podendo aceitar auxílio governamental algum, pois com ele perderiam a necessária independência, que é usada na defesa do patrimônio nacional assaltado e no esclarecimento honesto da população, têm que apelar para a generosidade do público. (...) É preciso que tal imprensa, de número já tão reduzido, não desapareça nem ensarilhe as armas. ${ }^{44}$

Tratava-se da UDN gráfica (que coexistiu ao lado das UDN's civil e militar), na expressão do jornalista Sebastião Nery. ${ }^{45}$ Portanto, Careta se situava no interior da rede de imprensa de oposição, por onde circulavam e eram (re)produzidos discursos parlamentares e manifestos partidários (sua face oficial), mas também chistes e boatos, charges e caricaturas, apelidos e versos, assacados contra o poder constituído (sua face informal). A revista participava, pois, da elaboração e difusão da cultura política liberal-udenista, forjada no enfrentamento do Estado Novo e na redemocratização. ${ }^{46}$ Uma cultura política definida pela partilha de valores, tradições, práticas e representações, tais como o liberalismo (político e econômico), o moralismo (contra a corrupção e as diversas formas de patrimonialismo, clientelismo e nepotismo), o bacharelismo (uma concepção elitista da política, contra a "demagogia populista" e o comunismo) e o anti-varguismo, em suas duas vertentes partidárias (surgidas nos salões e porões da ditadura): o PSD (amparado na "máquina pública") e o PTB (sustentado no sindicalismo de Estado). Em sua formulação, a cultura udenista produziu ainda uma singular interpretação da história, baseada na negação e crítica da chamada

44 BOB (Roberto Schmidt). O Homem da Vassoura. Careta, Rio de Janeiro, ano LI, n.2.647, p.3 e p. 34, 21/03/1959 45 NERY, Sebastião. Folclore político: 1950 histórias. São Paulo: Geração Editorial, 2002, p.32.

46 Sobre o conceito de cultura política, conferir: HUNT, Lynn. Política, cultura e classe na Revolução Francesa. São Paulo: Companhia das Letras, 2007; BERSTEIN, Serge. (org.). Les cultures politiques en France. Paris: Éditions du Seuil, 1999; BERSTEIN, Serge. Culturas políticas e historiografia. In: AZEVEDO, Cecília et al. (orgs.). Cultura política, memória e historiografia. Rio de Janeiro: Editora FGV, 2009, p.29-46; MOTTA, Rodrigo Patto Sá. Desafios e possibilidades na apropriação de cultura política pela historiografia. In: novos estudos. Belo Horizonte: Argvmentvm, 2009, p.13-37. 
"Revolução de 1930" e da ditadura do Estado Torvo, vistas como a matriz da "corrupção dos costumes políticos e da moralidade administrativa" no Brasil. ${ }^{47}$

Dessa forma, a análise da série iconográfica de Careta sobre Brasília permite refletir sobre o papel da sátira e da caricatura na produção da cultura política liberal-udenista, através do recurso ao humor, ao sarcasmo, ao ridículo e à ironia. A perspectiva adotada procura perceber seus usos e modos de funcionamento nos enfrentamentos políticos, na captação das tensões sociais e na fabricação de contra-imagens do poder. Mais do que simples entretenimento, as charges se constituíam em intervenção política, formando uma ideia-imagem de combate a partir da qual se elaborou uma interpretação crítica do projeto mudancista de Maracangalha.

Às vezes, uma única charge podia sintetizar toda uma análise de conjuntura (Figura 7). Assim, abrigado no alto de uma árvore seca, um perspicaz Jeca explica a um surpreso cidadão porque a "enchente" estava acontecendo: tudo começou com um "rio", nascido na "cordilheira da Ditadura" (Estado Novo), que se avolumara num "mar de lama" (segundo governo Vargas) até se transformar no atual "oceano" (segundo ano do governo JK), repleto de "sujeiras", tais como, uma gamela (de escândalos), um frasco (de negociatas), um tonel (de desfalques), um caixote (de contrabandos). Observando o diálogo, vemos uma pitoresca galinha, enquanto ao fundo, por detrás da árvore, espreita uma ameaçadora barbatana de tubarão (gíria popular para os especuladores, apontados como responsáveis pela inflação e pela carestia, uma ideia-imagem recorrente nas charges de Careta sobre a situação econômica do país).

Portanto, como resultante dos escusos interesses ligados a esse rubro e pútrido rio-mar-oceano de lama, o que seria Brasília? Seria uma nova Pampulhação, dando sequência aos descalabros de JK na prefeitura de Belo Horizonte? ${ }^{48}$ Afinal, os versos de Zé Povo já anunciavam que "Depois de feito o 'serviço'/A turma, com a bolsa cheia,/Quer paz, sossego... Por isso,/Brasília não tem cadeia". ${ }^{49}$

47 Para uma discussão dos elementos do udenismo, suas contradições e ambiguidades, cf. BENEVIDES, Maria Victoria de Mesquita. A UDN e o udenismo, p.241-275.

$48 \mathrm{O}$ trocadilho se refere às denúncias de negociatas envolvendo a venda de lotes durante as obras de urbanização da Pampulha, realizadas durante a gestão de JK em Belo Horizonte (1940-1945). Segundo editorial, os negócios imobiliários da Pampulha seriam o "paradigma" das negociatas da Novacap. Cf. BOB (Roberto Schmidt). Terra de ninguém. Careta, Rio de Janeiro, ano L, n.2.599, p.3, 19/04/1958.

49 Careta, Rio de Janeiro, ano LII, n.2.706, p.18, 07/05/1960. 


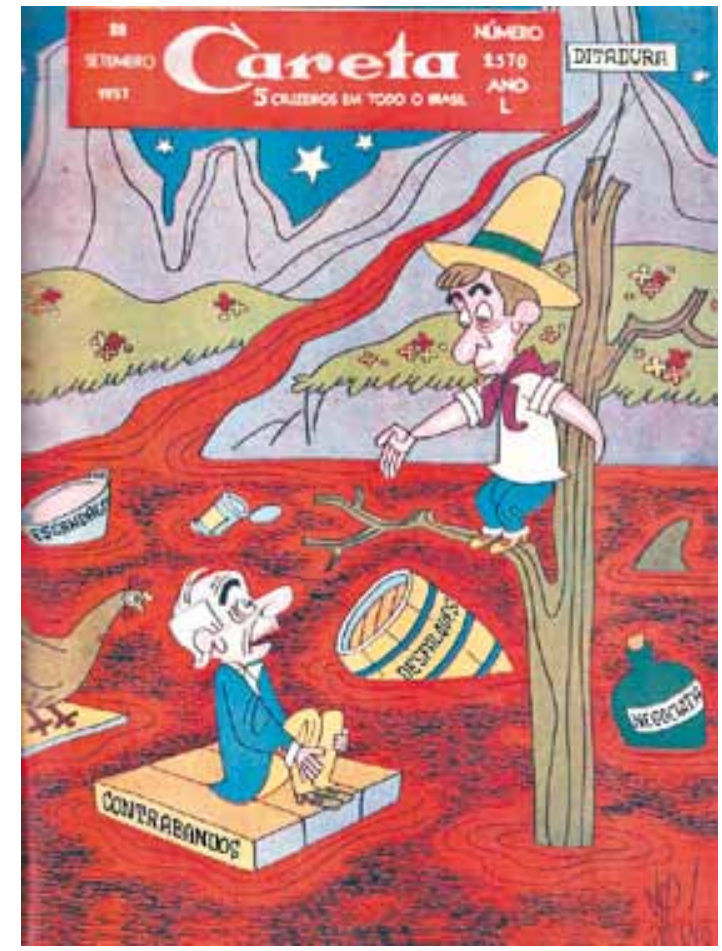

- Não era um rio de lama?!

Jeca - Isso foi no começo e lá nas cabeceiras - agora é um mar, um oceano, de cujo fundo só vem à tona sujeiras...

Figura 7. THÉO. O retorno (capa). Careta, Rio de Janeiro, ano L, n.2.570, 28 set. 1957.

\section{Da polêmica musical à distopia Brasiliæ}

Os embates em torno da nova capital, portanto, dividiam opiniões, expressando, por seu turno, os conflitos entre setores das elites políticas e econômicas, bem como entre diferentes projetos de Nação. A intensa propaganda governamental buscava seduzir os piotários (segundo Careta) com promessas de desenvolvimento econômico e integração nacional. Assim, segundo a lógica de que "alguns eram contra, muitos a favor e todos seriam beneficiados" (grifos nossos), a campanha incentivava a partida dos formadores das "gerações de amanhã", até mesmo da jovem mocinha a pedir carona, levantando discretamente a barra da saia e oferecendo à vista gulosa seus dotes generosos (Figura 8). Um estilo de propaganda que a verve popular logo transformou em piada. No Rojão de Brasília, o paraibano Jackson do Pandeiro, mesmo louvando as belezas do planalto e as "estradas que não têm fim", encerra a canção com uma jocosa advertência aos pretendentes: "Quem tiver de malas prontas/Pode ir que se dá bem/Leve 
todos os cacarecos/Leve seu xodó também/Este conselho é pros homens/ Porque mulher lá não tem". ${ }^{50}$

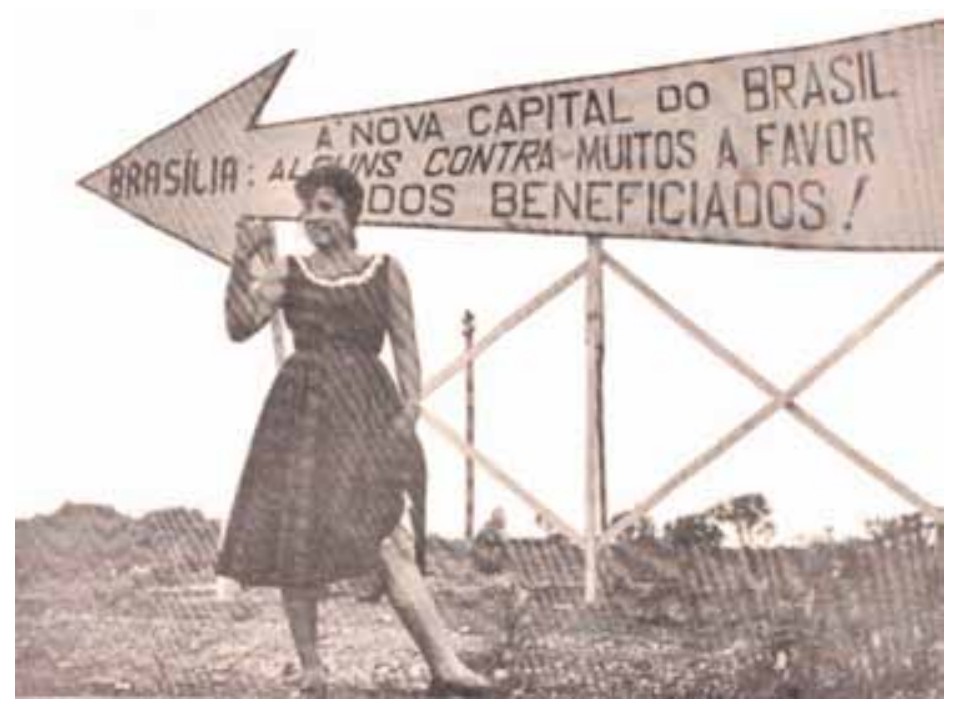

"Aqui se encontram hoje as gerações brasileiras de amanhã".

Figura 8. Reprodução de ORICO, Osvaldo. Brasil, capital Brasilia, p.105.

Dessa forma, configurou-se a polêmica musical de Brasilia, com posições a favor e contra, conferindo um colorido especial ao debate. Compreendendo diversos públicos, agentes socioculturais e media (imprensa escrita, rádio, TV, cinema), tal querela foi travada especialmente por meio de sambas, marchas e modinhas, mas envolveu ainda gêneros "nordestinos" (baião, côco e rojão), composições eruditas (hino e sinfonia) e gêneros estrangeiros (tango e bolero). ${ }^{51}$

Conforme Maria Alice Rezende de Carvalho, a prática social das polêmicas musicais acompanhou o processo de expansão do rádio e de nacionalização do samba, a partir dos anos 1930. A historiadora chama a atenção para a transformação das "letras dos sambas em objeto de infindáveis debates", o que "animou a produção do gênero e estabeleceu, fortemente, a associação entre samba e crítica ou, mais ainda, entre samba e sátira" (grifo nosso). Ainda segundo a autora, a música popular tornavase "uma forma de narrativa sobre a moderna tradição, capaz de expor o

50 JACKSON DO PANDEIRO. Rojão de Brasília [Rojão]. Jackson do Pandeiro, João do Vale [compositores]. In: Ritmo, melodia e personalidade de Jackson do Pandeiro. Rio de Janeiro: Philips, 1961. 1 disco sonoro, 33 1/3 rpm. Lado A, faixa 5 (3 min $12 \mathrm{~s}$ ).

51 Em nossa pesquisa, identificamos 37 canções e hinos, além de uma sinfonia (em 5 movimentos), formando o corpus da polêmica musical de Brasília. Nos limites deste artigo, apontaremos apenas algumas linhas de interpretação desses documentos sonoros, esperando aprofundar a análise em outra oportunidade. 
país ao conhecimento de si", numa linguagem ligada à experiência urbana que contribuía para a formação da opinião pública e ampliava o círculo de "intérpretes" da modernização. ${ }^{52}$

No mesmo sentido, o historiador Marcos Napolitano destaca o papel das querelas e polêmicas intelectuais e musicais, as quais, em sua diversidade, tinham como ponto comum o "ideal nacionalista", vinculando a canção a "projetos culturais e ideológicos mais ambiciosos", desde as "políticas culturais de promoção cívico-nacionalista" do Estado Novo (com o sambaexaltação) $)^{53}$ até a "perspectiva de engajamento" da cultura nacional-popular, com a canção de protesto. ${ }^{54}$

Contudo, é importante destacar que não conseguimos localizar na historiografia nenhuma referência à polêmica musical de Brasília, que parece ter sido relegada ao "esquecimento", salvo melhor juízo. Nossa hipótese é que tal "silenciamento" está ligado a alguns fatores: a) o mito dos "Anos Dourados", obscurecendo os aspectos conflitivos do período; b) o predomínio, no campo da história da música popular, de pesquisas sobre a ruptura da Bossa Nova (considerada um marco divisor de águas), ou então, c) de estudos sobre a música de protesto dos anos 1960. Assim, a querela político-musical dos anos JK acabou sendo diluída por esses vetores de interpretação.

Ademais, a polêmica de Brasília estava associada a duas vertentes da música popular existentes desde os anos 1930: de um lado, o samba-exaltação, e, do outro, a canção satírica (ou de oposição). ${ }^{55}$ Assim, podemos delimitar um primeiro conjunto formado pelas canções de exortação, uma variante juscelinista do samba-exaltação, cuja es-

52 CARVALHO, Maria Alice Rezende de. O samba, a opinião e outras bossas... na construção republicana do Brasil. In: CAVALCANTE, Berenice et al. (orgs.). Decantando a República: inventário histórico e político da canção popular moderna brasileira. v.1. Rio de Janeiro/São Paulo: Nova Fronteira/Fundação Perseu Abramo, 2004, p.39 e 51.

53 O samba-exaltação pode ser entendido como um gênero específico, marcado pelo caráter patriótico, de enaltecimento das belezas naturais e do povo mestiço, bem como pela "estética monumental", com arranjos orquestrais privilegiando a percussividade do samba e sua difusão nas ondas do rádio. Foi também nomeado de samba da legitimidade ou samba nacionalista (a "representação sonora da nação"), sendo apropriado pela ditadura varguista, interessada na promoção da música (erudita e popular) para a formação da "brasilidade". Sobre este ponto, cf. PARANHOS, Adalberto. A invenção do Brasil como terra do samba: os sambistas e sua afirmação social. História, Franca, v.22, n.1, p.107-108, 2003. E ainda: LIMA, Ricardo A. F. Ary Barroso e o engajamento da canção. In: XXIV SIMPÓSIO NACIONAL DE HISTÓRIA (ANPUH). História e multidisciplinaridade: territórios e deslocamentos: Anais do XXIV Simpósio Nacional de História. São Leopoldo: Unisinos, 2007 (CD-ROM).

54 Cf. NAPOLITANO, Marcos. História \& Música: história cultural da música popular. 3. ed. Belo Horizonte: Autêntica 2005, p.47-55. Segundo Arnaldo Contier, a canção de protesto "representava uma possível intervenção política do artista na realidade social do país, contribuindo assim para a transformação desta numa sociedade mais justa". Apresentando um forte apelo emotivo de enaltecimento afetivo do povo brasileiro, a música de protesto aproximava o marxismo e o romantismo, numa perspectiva de esquerda e revolucionária. Cf. CONTIER, Arnaldo Daraya. Edu Lobo e Carlos Lyra: o nacional e o popular na Canção de Protesto (Os Anos 60). Revista Brasileira de História, São Paulo, v.18, n.35, 1998. Disponível em: <http://www.scielo.br/scielo.php?script= sci_arttext\&pid= S0102-01881998000100002\&lng=pt\&nrm=iso > . Acesso em: 24 mar. 2012.

55 A noção é baseada na análise de Herman Lima sobre as relações entre charge e música carnavalesca (ver nota 5), bem como nos argumentos de Maria Alice Carvalho sobre a associação entre samba e sátira (política e social). A autora cita como exemplo a canção Com que roupa? (sucesso carnavalesco de Noel Rosa, em 1931), que foi adotada e parodiada tanto para fazer a crítica da indefinição política de Getúlio Vargas, quanto para satirizar a proibição de trajes "ousados" nos banhos de mar. Cf. CARVALHO, Maria Alice Rezende de. O samba, a opinião e outras bossas, p.50. 
pecificidade reside no apelo à mudança (o topos heroico da partida) e/ ou na louvação da nova capital, promovendo a legitimação do projeto nacional-desenvolvimentista e uma nova onda nacionalista, incensada ainda pela vitória do escrete canarinho na Copa do Mundo de 1958. Nesse conjunto, vale mencionar os sambas-exortação Vou pra Goiás (Nélson Gonçalves, 1957), ${ }^{56}$ Brasília (César Prates, 1957), ${ }^{57}$ Samba em Brasília (Ataulfo Alves, 1957) ${ }^{58}$ e Adeus, Mangueira (Trio de Ouro, 1958), bem como o côco-exaltação Homenagem a JK (Ari Lobo, 1959),,$^{59}$ além de uma dezena de composições (samba, marcha, hino, tango, bolero) feitas especialmente para a inauguração da Novacap em 21 de abril de 1960, com destaque para o samba-exaltação Brasília, Capital da Esperança (Jorge Goulart) ${ }^{60}$ e a apoteótica Brasília, Sinfonia da Alvorada (dos bossa-novistas Tom Jobim e Vinícius de Moraes). ${ }^{61}$

O segundo bloco da polêmica é formado pelas canções de oposição (ou sátira política e social), com composições marcadas pelo bom humor, pela ironia e pela irreverência, criticando diferentes aspectos da sociedade, sem, contudo, estar ligadas diretamente a um projeto político definido (no que diferem da canção de protesto, de tom épico e sério, num misto de realismo e romantismo que caracterizou o engajamento político de esquerda). ${ }^{62}$ Dentre as canções de oposição, é preciso distinguir entre aquelas com nítido perfil satírico-político (recebendo, em consequência, a censura oficial, com a proibição da reprodução pública), as paródias de sucessos do momento e aquelas canções que foram compostas sobre outros temas, sendo depois apropriadas e politizadas pela charge de humor. Neste último caso, além das citadas Maracangalha e Daqui não saio, se destaca a ressignificação do sucesso carnavalesco Me dá um dinheiro aí (Figura 9). ${ }^{63}$

56 GONÇALVES, Nélson. Vou pra Goiás [Samba]. Jorge de Castro, Nássara, Wilson Batista [compositores]. S.I.: RCA Victor, 1957. 1 disco sonoro, 78 rpm, lado B (2 min 40 s).

57 PRATES, César. Brasília [Samba-exaltação]. Dilermando Reis, Bastos Tigre [compositores]. São Paulo: Continental, 1957. 1 disco sonoro, 78 rpm, lado A (2 min $17 \mathrm{~s})$

58 ALVES, Ataulfo. Samba em Brasília [Samba]. . [compositor]. S.I.: s.n., 1957.

59 LOBO, Ari. Homenagem a JK [Côco-exaltação]. Gordurinha [compositor]. S.I.: RCA Victor, 1959. 1 disco sonoro, $78 \mathrm{rpm}$, lado A (2 min $57 \mathrm{~s})$.

60 GOULART, Jorge. Brasília, Capital da Esperança [Samba-exaltação]. Cid Magalhães, Ivo Santos [compositores]. S.I.: RCA Victor, 1960. 1 disco sonoro, $78 \mathrm{rpm}$, lado A (3 min $21 \mathrm{~s}$ ). Em entrevista, o cantor ressaltou o "clima nacionalista" vigente no país, levando-o a gravar, pela Continental (1959), uma coletânea com 12 sambas-exaltação dos anos 1930 e 1940, os quais adquiriam novos usos e significados no contexto do nacional-desenvolvimentismo e da redenção do futebol brasileiro. Cf. LENHARO, Alcir. Cantores do Rádio: a trajetória de Nora Ney \& Jorge Goulart e o meio artístico de seu tempo. Campinas, SP: Editora da UNICAMP, 1995 (Coleção Viagens da Voz), p.250.

61 JOBIM, Tom e MORAES, Vinícius. Brasília - Sinfonia da Alvorada [Sinfonia]. __. [compositores]. Rio de Janeiro: Columbia, 1961. 1 disco sonoro, 33 1/3 rpm. 5 faixas (35 min).

62 Este ponto é ressaltado por Waldenyr Caldas para diferenciar as composições de Juca Chaves da canção de protesto. Cf. CALDAS, Waldenyr. A cultura político-musical brasileira. São Paulo: Musa Editora, 2005, p.68-69. Em capítulo específico, o autor pretendeu analisar "a canção no governo de Nonô" (cap. III), contudo, se restringiu a algumas canções satíricas do menestrel Juca Chaves, sem vislumbrar o conjunto da polêmica musical.

63 FRANCO, Moacyr. Me dá um dinheiro aí [Marcha]. Homero, Ivan, Glauco Ferreira [compositores]. Rio de Janeiro: Copacabana, 1959. 1 disco sonoro, 78 rpm, lado A (2 min 36 s). Foi a canção-tema da chanchada Entrei de Gaiato (direção de J. B. Tanko, 1959). 


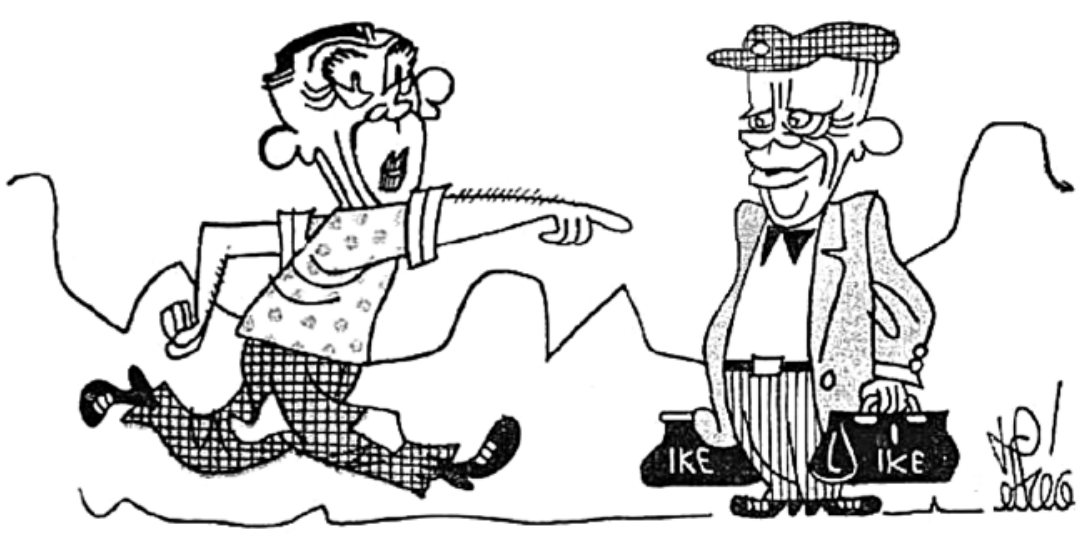

JK - Ei, você aí, me dá um dinheiro aí! ...

Figura 9. THÉO. Recepção. Careta, Rio de Janeiro, ano LII, n. 2.706, 13 fev. 1960.

Satirizando de forma implacável o mendigo JK, por ocasião da visita do presidente norte-americano Dwight Ike Eisenhower ao Brasil, a charge faz a crítica da política econômica, baseada em emissões inflacionárias de moeda e empréstimos externos, como forma de viabilizar o Plano de Metas e a construção da nova capital. Política financeira que foi duramente criticada pela revista desde o início do governo, logo alcunhado de "governo facadista", em função da gíria popular ("facada" = pedir dinheiro). Num momento em que a palavra "operação" estava na moda (vide a Operação Brasília e a Operação Pan-Americana), a administração Come-cheque estaria seriamente empenhada na OPEFA (Operação Facada), especialmente nas relações com os EUA e o FMI.

Nesse sentido, a mendicância e a "mordida" de JK Lott na recepção a Ike faziam referência a outro registro visual de enorme repercussão (Figura 10): a fotografia de Antônio Andrade do encontro de Juscelino com John Foster Dulles (secretário de Estado norte-americano), em agosto de 1958. A dubiedade extraordinária do instante caricatural suscitou acesa polêmica, com o governo brasileiro considerando algumas interpretações ofensivas à "dignidade nacional" e atacando a atitude do Jornal do Brasil em divulgar no exterior essa "infâmia", cometendo "crime de lesa pátria".

Careta, por sua vez, no artigo "Uma esmola pelo amor de Deus!...", movida "somente pelo amor à verdade, à verdade nua e crua", restabelece a "autenticidade" dos fatos. Embora longa, a citação possibilita saborear o estilo irônico e derrisório dos textos da revista:

Queremos lavrar nosso veemente protesto contra a cavilosa interpretação que os eternos descontentes, os negativistas contumazes, as cassandras agourentas e os flibusteiros da pena de certa imprensa rubra e torpe andaram espalhando, 
"urbe et orbe", a respeito daquele documento fotográfico histórico, interpretação segundo a qual estaria o preclaro Chefe do Governo Brasileiro solicitando, como um desses miseráveis mendigos de porta de igreja, uma esmolinha pelo amor de Deus! ao todo poderoso visitante; o Chanceler Negrão de Lima, estaria querendo "bispar" a escrita do Contas-Correntes do Sr. Foster Dulles; e a comitiva norte-americana estaria a debochar dos nossos governantes, rindo-se, na cara deles, do seu cinismo e irresponsabilidade. (...) A verdade histórica é a seguinte: quando o fotógrafo do Jornal do Brasil bateu a chapa (...), usava o Dr. Juscelino Kubitschek de Oliveira, digníssimo Presidente eleito da República dos Estados Unidos do Brasil, de toda a sua proverbial força de persuazão [sic], no sentido de convencer o Sr. Foster Dulles da necessidade de aceitarem os Estados Unidos da América do Norte um substancial empréstimo que o Brasil oferecia àquele irmão do Continente, a fim de o tirar da ameaça de bancarrota em que se encontrava. O Secretário de Estado norte-americano, não obstante a consulta do Contas Correntes Ihe mostrar que os Estados Unidos da América do Norte de há muito haviam ultrapassado sua linha de crédito, acabou, muito pesarosa e humilhadamente, por aceitar as generosas mãos que o Presidente brasileiro Ihe estendia. Quanto ao riso que aflora às faces dos auxiliares de Mr. Dulles, em lugar de serem de escárneo [sic] ou mofa, é, pelo contrário, de vivo contentamento pelo bom êxito da missão que havia trazido ao Brasil o bando precatório norte-americano. ${ }^{64}$

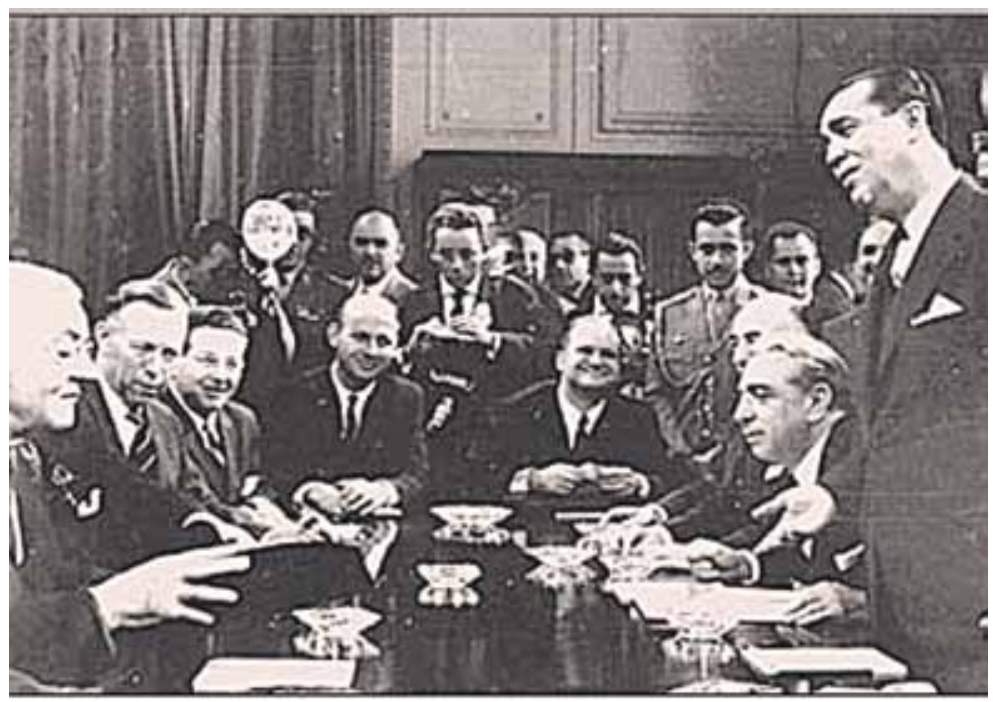

Figura 10. ANDRADE, Antônio. Tenha paciência, mister... (capa). Jornal do Brasil, Rio de Janeiro, ano LXVIII, n. 181, 06 ago. 1958.

Com o lançamento de Me dá um dinheiro aí no ano seguinte, foi quase automática a associação entre fotografia e música (que suscitou depois o 
equívoco de atribuir-se à foto original o mesmo título da canção), convergindo com o "facadismo" explorado nas charges de Careta e evidenciando os modos de circulação e apropriação de ideias-imagens na rede de imprensa ligada à cultura política liberal-udenista.

Voltando às canções de oposição, dentre aquelas com perfil político, destacam-se duas composições censuradas de Juca Chaves, Presidente Bossa Nova e Caixinha, obrigado, ironizando a "esperança" e o "otimismo" dos "Anos Dourados". ${ }^{55}$ Sobre a última, o sagaz e anônimo Espírito de Porco (comentarista político da Comédia infinita) observou que "compreende-se à vista da letra porque foi proibida: diz verdades e o 'governo' do nosso alegre JK não resiste à verdade". ${ }^{66} \mathrm{~A}$ modinha contrasta a melodia idílica e a voz suave com a sátira feroz da indigência que assolava o país ("A mediocridade é um fato consumado/na sociedade onde o ar é depravado"), vituperando a moral burguesa, o futebol, médicos, políticos, policiais e militares, com cada estrofe fazendo gentil e sarcástica saudação à sacrossanta Caixinha (marca registradora da corrupção), obrigado! ${ }^{17}$

Já Presidente Bossa Nova, se concentra nos vícios públicos e privados do Exmo. Senhor Presidente da República (uma caricatura musical), fazendo alusão ao absenteísmo aéreo, aos passeios da família presidencial (as "mineirinhas valsinhas", filhas de JK, em Versalhes), ao nepotismo ("mandar parente a jato pro dentista") e ao clientelismo (nomeação de amigos boêmios, como Dilermando Reis). ${ }^{68}$ Depois de enumerar tantos males, o menestrel encerra o samba ironizando, pelas vias do pleonasmo e da hipérbole, as pretensões de se estabelecer a modernidade no Brasil: "Isto é viver como se aprova/É ser um presidente Bossa Nova/Bossa Nova, muito nova, nova mesmo, ultranova...". ${ }^{69}$

Contudo, a mais direta e ácida canção de oposição foi, sem dúvida, Não Vou Pra Brasília, interpretada pelo grupo Os Cariocas, a qual jogou com uma argumentação muito usual contra o novo distrito federal: a contraposição entre o atraso (do campo, da selva, do deserto) e a civilização (da litorânea Belacap). Compositor de sambas (alguns deles satíricos) desde o início dos anos 1950, Billy Blanco conta, em suas memórias, que teve inspiração ao ver fotografias da Primeira Missa de Brasília (03 de maio de

65 Duas outras canções do cantor-compositor Juca Chaves também foram censuradas: o samba Mudança de Destino (ironizando a transferência: "Vou mudar o meu destino mudando de capital") e a modinha Brasil já vai à guerra (sobre a compra bilionária do porta-aviões Minas Gerais, apontado como sucata da Segunda Guerra Mundial).

66 ESPÍRITO DE PORCO. Comédia infinita. Careta, Rio de Janeiro, ano LIII, n.2.726, p.10, 24/09/1960.

67 CHAVES, Juca. Caixinha, obrigado! [Modinha]. In: _. As músicas proibidas de Juca Chaves. S.I.: ODEON, 1962. 1 disco sonoro, 33 1/3 rpm. Lado A, faixa 4 (3 min $\overline{19} \mathrm{~s})$.

68 O violonista e compositor era companheiro boêmio do presidente, ao lado de César Prates. O músico dava "aulinhas de violão" para JK e as filhas, sendo, por tão altos serviços prestados à República, nomeado para o bem remunerado cargo de delegado fiscal na Prefeitura do DF no... Rio de Janeiro, afinal não podia abandonar a boêmia carioca. Cf. PENALBER, Bianor. Regalo à custa da Nação. Careta, Rio de Janeiro, ano LII, n.2.708, p.35, 21/05/1960

69 CHAVES, Juca. Presidente Bossa Nova [Samba Bossa Nova]. In: . As duas faces de Juca Chaves. São Paulo: RGE, 1960. 1 disco sonoro, 33 1/3 rpm. Lado A, faixa 1 (2 min $10 \bar{s}$ ). 
1957), com "bispos, padres e índios a caráter", de onde sua "irreverência" sacou a canção, "naquele gênero que meu amigo Sérgio Porto [Stanislaw Ponte Preta] denominou com muita propriedade 'samba de costumes e diversões'".70

A performance d'Os Cariocas se inicia em tom cômico, com uma imitação caricatural de chefe indígena, dizendo: "Brasília uaiê, carioca bai sá e andá! Jabaculê!”, a seguir, todo o grupo grita úúúúúúúúúúú, batendo a mão sobre a boca, seguindo-se o som de tambores "tribais" e nova rodada de úúúúúúúúúúú. ${ }^{71}$ Logo, o samba de breque ataca, com seus floreios e telecotecos:

Não vou!... Não vou!... Eu não sou índio nem nada,/Não tenho orelha furada,/ Nem uso argola pendurada no nariz./Não uso tanga de pena,/E a minha pele é morena/Do sol da praia onde nasci,/E me criei feliz./Não vou, não vou pra Brasília,/ Nem eu, nem minha família,/Mesmo que seja pra ficar cheio da grana./A vida não se compara,/Mesmo difícil e tão cara,/Quero ser pobre/Sem deixar Copacabana./ Não! Não vooooooou!...

À utopia nacional-desenvolvimentista da Novacap, a canção satírica de Billy Blanco contrapôs "o mito de uma vida paradisíaco-cosmopolita à beiramar", forjado com a expansão urbana da Belacap rumo à zona sul (década de 1950), mito sintetizado na imagem do barquinho bossa-novista. ${ }^{72}$ Mas, antes mesmo da Bossa Nova, Billy Blanco havia composto, em parceria com o estreante Tom Jobim, a Sinfonia do Rio de Janeiro (1954), uma "suíte popular em tempo de samba" (exaltação), que atualizava o mito edênico, unindo Copacabana à "tradição" do morro. ${ }^{73}$

O sucesso de Não vou pra Brasília provocou várias réplicas, a começar pela censura disfarçada do governo federal, assim narrada pelo compositor:

Meu presidente preferido apenas pediu ao Moacyr Arêas, diretor-geral da Rádio Nacional [oficial], que segurasse as pontas e não desse audiência ao samba na rádio, na época a mais ouvida no continente. Forma delicada de vetar sem proibir. Mas o samba tocou nas outras emissoras, bailes, dancings, parques de diversão, circos, clubes, gafieiras, etc. (...) O que conta é o samba alegre, levando meu espírito brincalhão de sempre e ganhando as ruas para consolo do sacana do carioca e meu. ${ }^{74}$

Já em seu "cartão de visita", Osvaldo Orico (o camelô de Brasília, segundo Careta) buscou relacionar a canção de Billy Blanco com o medo do

70 BLANCO, Billy. Tirando de letra e música. 2. ed. Rio de Janeiro: Record, 2001, p.39-40.

71 OS CARIOCAS. Não vou pra Brasília [Samba]. Billy Blanco [compositor]. Recife: Mocambo, 1957. 1 disco sonoro, 78 rpm, lado A (2 min 39 s). Jabaculê é gíria para dinheiro de suborno e corrupção.

72 RISÉRIO, Antônio. Caymmi, p.68.

73 Cf. BLANCO, Billy. Tirando de letra e música, p.75-83.

74 BLANCO, Billy. Tirando de letra e música, p.40. A censura também é citada por CIAMBARELLA, Alessandra. "A tradição abre as portas à modernidade": o Rio de Janeiro e a transferência da Capital Federal (1956-1960). In: 
"carioca de quatro costados... perder as regalias a que tem direito como sede do governo", observando que o "samba [é] por sinal delicioso, divertido, e..., se não nos convence a ficar, nos convence a dançar". Para o diplomata, a disposição popular, ao contrário, estaria registrada em versos "anônimos", "encontrados por acaso num dos capões do planalto, e ali perdidos, certamente, por algum 'pau-de-arara'". Compostos em cordel pela persona poética de um caipira-escrivão da "nova descoberta do Brasil", os versos oferecem uma dupla resposta aos ataques musicais à Novacap, incluindo sintomaticamente a refutação de Maracangalha (sendo, portanto, índice da repercussão e eficácia simbólica da charge de Théo):

\begin{abstract}
Vamo acabá com a quisilia [polêmica],/vamo mêmo pra Brasília,/que se encontra à nossa espera;/(...)/Eu vou mesmo pra Brasília,/levando toda família/e mais os meu cacareco./Não disponho de um Visconte/mas vou furá o horizonte/montado num teco-teco./(...)/Eu vou, eu vou prá Brasília,/levando toda a família,/blaquetai, lencinho olraite,Nou mostrá como o caipira/com dois goles de uísque vira/pessoa do café-soçaite./(...)/Depois de tomá caninha,/ou a gostosa cabacinha,/eu, Pero Vaz de Caminha,/escrevo esta carta a El Rey:/digo ao povo que trabalha,/não vou prá Maracangalha,/mas para Brasília irei. ${ }^{75}$
\end{abstract}

Contrastando com o redivivo escrivão cabralino, os críticos, ao retomar e reformular o topos imemorial da oposição campo x cidade (cristalizado na cultura ocidental), ${ }^{76}$ duvidavam radicalmente da possibilidade da Novacap se viabilizar, tornando-se base de uma "nova civilização" nos sertões tropicais (mito alimentado tanto pelo "sonho" de Dom Bosco e o nacionaldesenvolvimentismo, quanto pelo modernismo urbanístico e arquitetônico de Lúcio Costa e Oscar Niemeyer). Nesse sentido, o tema do "deserto" ou "selva" de Brasília foi frequente em Careta.

Após a inauguração, por exemplo, o lápis de Théo compôs um soberbo Faraó Jukelinotep (Figura 11), sentado num trono de iniquidades, composto de incontáveis tijolos (suborno, vida cara, fraudes, emissões, corrupção, negociatas, déficits, filhotismo, sinecuras, demagogia, burocracia, inflação, desfalques etc.). Despreocupado, o Deus-Sol está despoticamente "governando" no vazio, enquanto é incensado e adorado por obedientes súditos (o Legislativo e o Judiciário, copio\$amente corrompido\$ e rebaixado\$ para aceitar a transferência).

FERREIRA, Jorge. (org.). O Rio de Janeiro nos jornais: ideologias, culturas políticas e conflitos sociais (1946-1964) Rio de Janeiro: 7 Letras, 2011, p.151-152. Contudo, a autora reduz a amplitude da polêmica musical a apenas um "duelo de sambistas", travado entre Billy Blanco e Ataulfo Alves, seguindo, nesse ponto, uma reportagem de Veja. Cf. RODRIGUES, Sérgio. Encanto não se transfere. Veja, Especial Brasília 50 anos: o nascimento de uma nação. Disponível em: < http://veja.abril.com.br/ especiais/brasilia/encanto-nao-se-transfere-p-124.html> . Acesso em: 23 mar. 2012.

75 Cf. WILLIAMS, Raymond. O campo e a cidade na história e na literatura. São Paulo: Companhia das Letras, 1990

76 LACERDA, Carlos. Discurso Parlamentar. Anais da Câmara dos Deputados. Rio de Janeiro: Serviço Gráfico do IBGE, v.XXII, ago. 1957, p.733, apud MOREIRA, Vânia M. L. Brasília, a construção da nacionalidade, p.215. 
A charge faz ainda referência a um dos temores da oposição, segundo Vânia Moreira: a possibilidade de um "golpe continuísta" que garantisse a permanência de Juscelino no poder, pois "a opinião majoritária da UDN considerava que o Congresso estava sendo 'silenciado' por meio do seu insulamento em Brasília", onde não haveria cobertura adequada da imprensa (já sob censura parcial) e nem pressão popular sobre o Executivo. ${ }^{77} \mathrm{~A}$ nova capital, localizada no vácuo do planalto central, estaria conectada, portanto, a um projeto autoritário, pois "quem tiver a chave dos tanques em redor de Brasília terá a chave do Brasil", profetizou o deputado Carlos Lacerda. ${ }^{78} \mathrm{~A}$ frase, de aparência premonitória do golpe de 31 de março de 1964, em verdade se referia ao contragolpe de 11 de novembro de 1955 (quando o general Lott garantiu a posse de JK e o início da "tutela militar") e à linha de continuidade do rio-mar-oceano de lama (Figura 7), segundo a leitura histórica da cultura liberal-udenista. Invertendo o sentido de um antigo ditado alemão sobre a cidade medieval, a perspectiva adotada pela oposição seria: "os ares da cidade respiram ditadura".

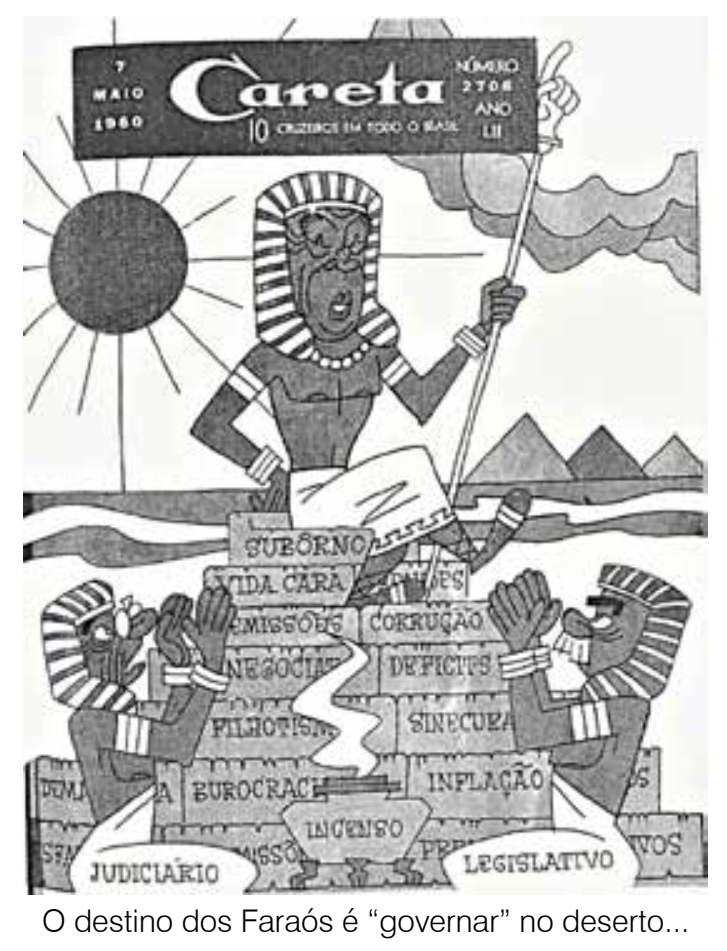

Figura 11. THÉO. Capa. Careta, Rio de Janeiro, ano LII, n. 2.706, 07 maio 1960.

77 MOREIRA, Vânia M. L. Brasília, a construção da nacionalidade, p.231.

78 LACERDA, Carlos. Discurso Parlamentar. Anais da Câmara dos Deputados. Rio de Janeiro: Serviço Gráfico do IBGE, v.XXII, ago. 1957, p.733, apud MOREIRA, Vânia M. L. Brasília, a construção da nacionalidade, p.215. 
Assim, verifica-se que, ao se transportar para o "deserto", o esquema de poder (nascido e alimentado nas entranhas do Estado Novo) só poderia se autorreproduzir em suas tendências autoritárias e patrimoniais, abrindo o flanco para o retorno da ditadura. Ou, em outros termos, o atraso só poderia gerar o próprio atraso, pois nada de qualitativamente novo, civilizatório e democrático poderia frutificar em Brasília (a cidade surgia, portanto, natimorta). Eis a desconfiança fundamental de Careta em relação à repetição exaustiva e superlativa do discurso do "moderno" e do "novo" pela propaganda oficial. "Novacap, muito nova, nova mesmo, ultranova...".

Ademais, a charge do Faraó Jukelinotep estabelece um necessário contraponto crítico à imagística das festas de inauguração, marcadas por toda pompa e suntuosidade requeridas pela monumentalidade do signomor da modernidade. AD MAJOREM JUKELINOTEPIS GLORIAM. ${ }^{79}$

Dentre as iniciativas, uma tornou-se alvo preferido dos chistes e piadas: a moeda de ouro comemorativa (Figura 12), com o nome e a efígie de JK, acompanhados da expressão CREATOR BRASILIAE - uma alusão à lenda de fundação de Roma, que enaltecia a figura do presidente, comparado a Rômulo e Remo, míticos pais fundadores da Civitas no mesmo dia XXI Aprilis. Da moeda, acompanhando a análise do filósofo e historiador Louis Marin sobre a "eficácia social da imagem" na legitimação do Estado absolutista francês (com o Rei-Sol Louis XIV), pode-se afirmar que é a representação icônica do soberano que "oferece um resumo em forma de quadro", pois "mostrar a história do rei em seu ícone é fazer com que seja narrada", com a durabilidade e brilho do ouro apontando o esplendor e glória perpétuos da monarquia. A moeda torna-se, portanto, um "signo monumental do poder absoluto". 80

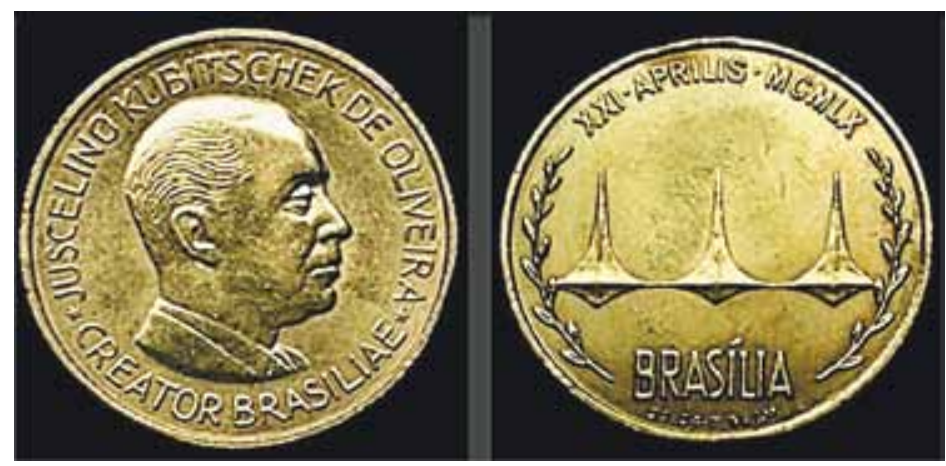

Figura 12. CREATOR BRASILIAE (Medalha comemorativa da inauguração da Novacap). Disponível em: <http://www.moedasecedulas.com>. Acesso em: 17 mai. 2011.

79 Para maior glória de Juscelino! Cf. Careta, Rio de Janeiro, ano LII, n.2.661, p.3, 27/06/1959.

80 Apud RICOEUR, Paul. A memória, a história, o esquecimento. Campinas, SP: Editora da Unicamp, 2007, p.278-281. 
Já Careta, ao contrário, em lugar do elogio do poder, promoveu a desconstrução satírica da cidade modernista e do culto à personalidade do presidente, por meio de seu deslocamento para o "deserto incivilizado", onde foram perpetuadas as estruturas do atraso, materializadas nas "obras faraônicas" da Nova-Velha-cap. A "Cidade dos Reis", no sertão goiano, foi "traçada por um louco [Lúcio Costa], arquitetada por um maluco [Oscar Niemeyer] e edificada por um malandro [Israel Pinheiro], para gáudio, fama e memória de um cabotino [JK]". ${ }^{81}$ Nesse sentido, a revista chegou mesmo a desconfiar que o sarcófago de Jukelinotep estivesse sendo construído, secretamente, no subsolo da Catedral-Pirâmide. ${ }^{82}$

E assim, estava (a)fundada Maracangalha, a nova capital dos Estados Unidos do Brasil, cidade-síntese das mazelas e vícios (públicos e privados) da República, uma "cidade fantasma", destinada a se tornar "símbolo da avacalhação" nacional. Brasiliæ era uma "aventura das Mil e Uma Noites" do Creator Inflacionis, um "alibabesco empreendimento" voltado para a criação de um moderno cemitério, onde se enterraram bilhões e bilhões de cruzeiros, para não falar das negociatas da nova Pampulhação.

De cidade-ideal dos sonhos modernistas, nacionalistas e desenvolvimentistas (que apostavam no futuro), a nova capital foi transfigurada política e esteticamente nos textos e charges da revista, que, através das armas do sarcasmo, da ironia e da sátira, a reconstruiu como utopia negativa e autoritária (segundo a leitura udenista do passado recente). Ou melhor, rindo, Careta a reinventou como malandræ distopia Brasiliæ. Passados mais de 50 anos de fundação, quais representações da nova capital permanecem ativas no imaginário político nacional?

"Eu vou pra Maracangalha, eu vou...".

81 BOB (Roberto Schmidt). Brasileiro, acorda! Careta, Rio de Janeiro, ano LII, n.2.710, p.3 e 38, 04/06/1960. 82 O FARAÓ contemporâneo. Careta, Rio de Janeiro, ano LII, n.2.665, p.24-5, 25/07/1959. 